\title{
Effects of microalgal diet on growth, survival, biochemical and fatty acid composition of Ruditapes decussatus larvae
}

\author{
Jose Andrés Aranda-Burgos, Fiz da Costa ${ }^{*}$, , Susana Nóvoa, Justa Ojea, Dorotea Martínez-Patiño
}

Centro de Investigacións Mariñas, Consellería do Medio Rural e do Mar, Xunta de Galicia, Muelle de Porcillán s/n, 27700 Ribadeo, Lugo, Spain

${ }^{1}$ Present address: Ifremer, Laboratoire des sciences de l'Environnement Marin (UMR 6539, LEMAR) 29280 Plouzané, France.

*: Corresponding author : Fiz da Costa, email address : fiz.da.costa.gonzalez@ifremer.fr

\begin{abstract}
:
Successful bivalve larval growth and survival depend on stored reserves provided by diet. The aim of this study was to evaluate the effects of microalgal diet on growth, survival, together with biochemical and fatty acid composition during larval development in grooved carpet shell (Ruditapes decussatus). Four mono- and multi-species diets were tested: (1) Isochrysis galbana, Pavlova lutheri and Chaetoceros muelleri (1:1:1, IPC); (2) I. galbana, P. lutheri and C. muelleri (1:1:2, IP2C); (3) I. galbana and $P$. lutheri $(1: 1, I P) ;(4) C$. muelleri $(C)$. Our results showed that feeding regime greatly influenced larval growth and survival, as well as biochemical and fatty acid composition. Higher growth and survival rates were observed in the IPC, IP2C and C diets, which all include C. muelleri. Despite the fact that the larvae fed with IP exhibited the lowest length at settlement and survival, they stored more total lipids than any of the diets including $C$. muelleri. The IP and IPC diets exhibited a higher percentage of total lipids, whereas IP2C and C showed a higher proportion of proteins. Lipid and carbohydrate concentration in these diets negatively affected growth and growth and survival of the larvae, respectively. Protein content of the larvae was however positively related to larval survival, whereas lipid content of the larvae negatively affected growth. Fatty acid (FA) profile of neutral lipids $(\mathrm{NL})$ and polar lipids $(\mathrm{PL})$ of 22-day-old larvae clearly reflected the FA proportion of each diet. Dietary $\mathrm{DHA}$ and DHA in NL of the larvae were negatively related to larvae growth. DHA incorporation into PL in larvae fed with DHA-deficient diets was compensated by an enrichment in EPA, 18:0dma, 22:5(n-3) and 22:2 non-methylene-interrupted dienoic FA. According to these results, the presence of $C$. muelleri in the diet seems to promote better growth and survival of $R$. decussatus larvae.
\end{abstract}

\section{Highlights}

We study the impact of four microalgal diets on biochemical and fatty composition of Ruditapes decussatus larvae $\rightarrow R$. decussatus larval diets may include the diatom Chaetoceros muelleri Increasing lipid and carbohydrate contents of the diets may reduce larval growth and survival respectively DHA deficiencies in the diet may not have deleterious effects on $R$. decussatus larval development Dietary AA is important for larval development.

Keywords : Ruditapes decussatus ; Larvae ; Diets ; Biochemistry ; fatty acids 


\section{Introduction}

The grooved carpet shell Ruditapes decussatus is distributed along the coastal and estuarine areas from the North Sea to Senegal and along the Mediterranean Sea, where it lives buried or semiburied in sand or mud, mainly in the intertidal zone, although it also inhabits subtidal zones (Vela and Moreno, 2005). It is the most appreciated native clam species in Spain, and it is also harvested in France, Italy, Portugal and Tunisia. Its capture production accounted for 1,349 tons in 2009 (FAO, 2010). The same source also recorded an aquaculture production of 2,052 tons and a market value of approximately \$20 million. $R$. decussatus is the clam species preferred by consumers due to its delicate taste and meat texture, also being the most expensive clam species in Europe. Its market value can reach up to 4-fold the price of any other clam species (Fernández et al., 2000). The Galician coast (NW Iberian Peninsula) is well known for its shellfish production, which has great economic and social importance (Beiras and Albentosa, 2004). Nevertheless, culture of this clam is clearly limited by the availability of natural seed (Ojea et al., 2008). Therefore, hatchery production is of the utmost importance as a way to reinforce natural recruitment in order to restock natural beds which are threatened due to over-fishing.

Nutrition is one of the dominant factors influencing bivalve larval growth and survival, and has been extensively reviewed in Marshall et al. (2010). Live microalgae are traditionally used as food for bivalves in mollusk hatcheries (Pernet et al., 2003). The criteria for selecting a suitable algal diet for bivalve larvae must be based on form, mobility, size, toxicity and the ability of the larvae to trap, ingest, digest and assimilate the algae (Marshall et al., 2010). Persoone and Claus (1980) identified the microalgae Isochrysis galbana, Isochrysis sp. (T-ISO), Pavlova lutheri, Tetraselmis suecica, Pseudoisochrysis paradoxa, Chaetoceros calcitrans and Skeletonema marinö̈ as important strains for bivalve feeding.

Food value is determined largely by biochemical composition (lipid, carbohydrate and protein). The viability of the larvae may be limited by the accumulation and/or utilization of energy substrates, either lipids as in Ostrea edulis (Helm et al., 1973; Holland and Spencer, 1973) or proteins during settlement as in Crassostrea gigas (Barlett, 1979) and O. edulis (Rodriguez et al., 1990). Carbohydrates may play a role in the optimal utilization of other reserves during metamorphosis, such as proteins, as in Crassostrea virginica and C. gigas (Haws et al., 1993). In the starved larvae of $R$. decussatus neutral 
lipids have been identified as the most abundant lipid constituents and the principal source of energy, followed by protein, with very little energy contribution from carbohydrate (Matias et al., 2011). Essential fatty acids (EFAs), particularly the omega-3 fatty acids eicosapentanoic acid (20:5(n-3), EPA) and docosahexanoic acid (22:6(n-3), DHA), are important for growth and development (Langdon and Waldock 1981) because they are major membrane components (Hendriks et al., 2003) and possible modulators of membrane function (Palacios et al., 2005). Moreover, the omega-6 fatty acids docosapentanoic acid (22:5(n-6), DPA) and arachidonic acid (20:4(n-6), AA) have been identified as potential modulators for growth and survival of the larvae (Pernet et al., 2005) and post-larvae in bivalves (Milke et al., 2008). Nevertheless, these EFAs must be supplied exogenously due to the very limited and/or absent capability of their synthesis in bivalves (Chu and Greaves, 1991; Laing et al., 1990; Waldock and Holland, 1984).

It is widely accepted that mixed diets better meet the nutritional requirements of bivalve larvae than unialgal diets. A combination of two or three highly nutritional microalgal species, including a suitably sized diatom and a flagellate, invariably provide improved rates of larval growth and development than single species diets (Helm et al., 2004). I. galbana is a worldwide used food supply for cultured suspension-feeding bivalves, and Isochrysis sp., P. lutheri and Chaetoceros sp. are the most common species used to feed the larvae, early juvenile and broodstock (during hatchery conditioning) of bivalve molluscs, due to their good nutritional properties (Brown, 2002).

In spite of the R. decussatus's great commercial importance, studies on its nutritional requirements are very scarce. Currently, there is little information on diets to feed spat (Albentosa et al., 1996, 1997; Fernández-Reiriz et al., 1998, 1999; Pérez-Camacho et al., 1998) and larvae (Matias et al., 2011), but to our knowledge no previous study has dealt with the fatty acid composition of larvae fed with mono- and multi-species diets. Therefore, the aim of the present work was to determine the effects of the most widely used microalgal diets (mono- and multi-species diets) on growth and survival, as well as biochemical and fatty acid composition in $R$. decussatus larvae.

\section{Materials and methods}

\subsection{Microalgae culture}


The microalgae I. galbana, $P$. lutheri and C. muelleri were grown in a continuous culture system in 400L polyethylene bags held in plastic mesh frames, based on that used by SeaSalter Shellfish Company Ltd. (Farrar, 1975). Inocula of these algae were part of an own culture collection of our institute and were kept in an isothermal chamber in $20 \mathrm{~mL}$ tubes under axenic conditions. Inocula were transferred to $250 \mathrm{~mL}$ Erlenmeyer flasks and then cultured in $2 \mathrm{~L}$ and $6 \mathrm{~L}$ glass carboys at a temperature of $19 \pm 1^{\circ} \mathrm{C}$ under continuous illumination at 180-220 $\mu$ photons $\mathrm{m}^{-2} \mathrm{~s}^{-1}$. Seawater at ambient salinity (32-33ppt) was 1- $\mu \mathrm{m}$ filtered, autoclaved and enriched with sterilised Algal-1 medium (supplied by Nutrición Avanzada, S.A., A Coruña, Spain). Microalgae inoculation of the continuous system was performed with $6 \mathrm{~L}$ glass carboys at late-exponential phase and previously checked under a microscope to avoid including any contamination and ensure the purity of the culture. Culture bags were illuminated by natural and artificial light under a photoperiod regime of 18:6 hours of light: darkness in a greenhouse. The artificial illumination was provided by vertical "daylight” fluorescent lamps (Philips TL-D) at 180-220 $\mu$ photons $\mathrm{m}^{-2} \mathrm{~s}^{-1}$. Incoming water was sterilized by pasteurization at $75^{\circ} \mathrm{C}$ for 30 minutes. Continuous aeration was provided to prevent the algae from settling. Moreover, $\mathrm{CO}_{2}$ addiction allowed $\mathrm{pH}$ maintenance between 7 and 8 . Seawater at ambient salinity $32-33$ ppt was maintained at $21 \pm 1^{\circ} \mathrm{C}$, and was enriched with the Solution $\mathrm{C}$ medium, which includes a mixture of mineral salts, nitrate and phosphate. Culture medium was added constantly ( $1 \mathrm{~mL}$ per L of algal culture), whereas the supply of sodium silicate, in the diatom culture, was added twice a week. Algae were harvested when the culture had reached the exponential growth phase and algal culture is maintained in this phase during 2 months under a dilution rate of 12.5 day $^{-1}$. Each species used in this experiment is harvested using a small pipe with a tap at the bottom of each bag and inspected daily under the light microscope. Before being used as food, algal cells were counted with a Bürker-Turk counting chamber and algal mixtures prepared for their distribution to larval cultures.

\subsection{Broodstock conditioning}

Adult specimens of $R$. decussatus were collected by rake in June 2010 in a natural bed in an intertidal zone of Cambados in Ría de Arousa (4250`N; 08²0’W) (Galicia, NW Spain). Then, clams were transferred cooled at $4^{\circ} \mathrm{C}$ to our hatchery facilities. At Centro de Cultivos de Ribadeo-CIMA, broodstock were conditioned in $200 \mathrm{~L}$ rectangular tanks at $18 \pm 1^{\circ} \mathrm{C}$ in an open circuit at ambient salinity 
of 32-33 ppt, with a continuous supply of a mixture of I. galbana, P. lutheri, T. suecica, Chaetoceros sp. and S. marinö̈ in equal proportions, representing a ration of $6 \%$ of dry meat weight in dry algal weight per day.

For spawning induction, 90 adult clams $(44.8 \mathrm{~mm}$ and $18 \mathrm{~g}$ of average length and weight respectively) were cleaned and kept dry at $4^{\circ} \mathrm{C}$ for $12 \mathrm{~h}$. Then, clams were placed in a tray with UVsterilized seawater at ambient salinity of 32-33 ppt and without aeration for spawning induction. Individuals were subjected to thermal shock, with temperatures up to $25^{\circ} \mathrm{C}$ for $2 \mathrm{~h}$, decreasing to $14^{\circ} \mathrm{C}$ for $30 \mathrm{~min}$. A total of 2 cycles were performed. Additional stimulus was provided by adding gametes stripped from one of the conditioned bivalves and microalgae (T. suecica). Each spawning specimen was quickly transferred into individual receptacles for the release of sperm or eggs, thus avoiding polyspermy. Once spawning was completed, sperm from several males was pooled and added to the container, at $20 \pm 1^{\circ} \mathrm{C}$, with oocytes to obtain synchronous fertilization. After counting, fertilization was performed at a ratio of 50 spermatozoids per oocyte. After fertilization, the eggs were sieved through a 45- $\mu \mathrm{m}$ mesh screen to eliminate excess sperm. Two hours after fertilization, when the embryos have reached the 4-cell stage, embryos were transferred to 500L larval culture tanks with aerated and filtered UV-irradiated seawater at a temperature of $20 \pm 1^{\circ} \mathrm{C}$. The density of the embryos was adjusted to 35 embryos $\mathrm{mL}^{-1}$. No food was supplied during embryo incubation.

\subsection{Larval culture}

The experimental design used in larval rearing was based on the routine work of a hatchery, i.e. the effect of diet on larval culture was evaluated at an intensive or industrial scale (large volumes and high density) and not at laboratory conditions (small volumes and low density). The experiment started on day 2 post-fertilization (at the stage of early D-veliger larvae). After sieving the larvae through a 60$\mu \mathrm{m}$ mesh screen, they were transferred to a 5-L beaker. Filtered seawater was added to a known volume. With an automatic pipette set at $50 \mu \mathrm{L}, 5$ replicate subsamples were taken of the contents, while agitating the contents of the beaker, with a suitable diameter perforated plunger. Larvae were counted using a light microscope.

Then, D-larvae were transferred to $150 \mathrm{~L}$ tanks at an initial density of 10 larvae $\mathrm{mL}^{-1}$. Larvae were randomly split into eight batches for duplicate exposure to four nutritional regimes: diets 1: $I$. 
galbana (4.8-5.5 $\mu \mathrm{m}$ diameter), $P$. lutheri (5.3-5.8 $\mu \mathrm{m}$ diameter) and $C$. muelleri (4.6-6.4 $\mu \mathrm{m}$ diameter)

(1:1:1, IPC); 2: I. galbana, P. lutheri and C. muelleri (1:1:2, IP2C); 3: I. galbana and P. lutheri (1:1, IP); 4: C. muelleri (C). All multi-species diets were prepared in cell volume equal proportions. Food was added daily to each tank at a rate of 40 cells $\mu \mathrm{L}^{-1}$ as an initial ration and 70 cells $\mu \mathrm{L}^{-1}$ as maximum ration at the end of the experiment. The ration provided varied with culture age (Table 1), but was always over larval feeding requirement standards found in the literature (e.g. Rico-Villa et al. (2006); Yan et al. (2006)). The temperature was set at $21 \pm 1^{\circ} \mathrm{C}$ and controlled by a thermostat. Seawater was completely renewed every two days using $1-\mu \mathrm{m}$ filtered, UV-sterilized seawater. Salinity throughout the larval rearing was $32 \pm 1$ ppt. D-larvae and pediveligers from each larval replicate were sampled to determine mean shell length and survival. Larvae were collected with nytex screens and shell length was measured for 100 randomly selected individuals per tank using a binocular microscope (Nikon Labophot-2) connected to an image analyzer (NIS-Elements BR 3.0 Nikon). Survival at pediveliger stage was determined after sieving the larvae, transferring them to a known volume beaker and sampling of 5 replicate subsamples of $50 \mu \mathrm{L}$ that were counted under a light microscope. Survival was based on initial number of 2-day-old larvae and larval performances reported in the present work related to the whole population. At day 22, pediveliger larvae were ready to settle and the experiment was finished.

\subsection{Biochemical and fatty acid analysis}

Samples of the diets $(n=3,80$ millions of cells per diet $)$ and larvae $(20,000$ larvae per triplicate on day 2 (D-larvae) and 10,000 larvae per tank on day 22 (settlement)), were collected for biochemical and fatty acid analysis. At the end of the experiment all tanks were drained and larvae were sieved and transferred to a 1-L beaker. Filtered seawater was added to a known volume. With an automatic pipette set at $50 \mu \mathrm{L}, 5$ replicate subsamples were taken of the contents while agitating the contents of the beaker, with a suitable diameter perforated plunger. Larvae were counted using a light microscope.

Samples of microalgae and larvae for gross biochemical analysis were collected directly in flasks, washed with 3\% ammonium formate, and centrifuged at $4000 \mathrm{rpm}$ for $5 \mathrm{~min}$.

Then the supernatant was discarded. All samples were frozen at $-20^{\circ} \mathrm{C}$,dried-frozen, and stored at $-20^{\circ} \mathrm{C}$. 
Dry weight of the larvae was determined. Separate samples of microalgal diets $(n=3)$ and larvae for fatty acids (FAs) analysis were filtered through to pre-combusted at $450^{\circ} \mathrm{C}$ Whatman $\mathrm{GF} / \mathrm{C}$ filters, washed with $3 \%$ ammonium formate and stored in a $\mathrm{CHCl}_{3}-\mathrm{MeOH}$ mixture $(2: 1, \mathrm{v} / \mathrm{v})$ under nitrogen at $-20^{\circ} \mathrm{C}$. The microalgal diets were sampled at the exponential phase of culture.

Lyophilized samples were homogenized in $400 \mu \mathrm{L}$ distilled water using a sonicator. Lipids were extracted with chloroform/methanol (1:2 v/v) (Bligh and Dyer, 1959). Then, the supernatant was washed with chloroform/water $(1: 1 \mathrm{v} / \mathrm{v})$ and the test tubes were centrifuged. The supernatant was removed and the residue was evaporated to dryness in a vacuum oven at $60^{\circ} \mathrm{C}$. The residue was transferred as a chloroform solution to a volumetric flask and diluted to exactly $2 \mathrm{~mL}$. Aliquots were collected to determine total lipids using the sulfuric acid-charring method described by Marsh and Weinstein (1966), with tripalmitine as standard. Protein was assayed as described by Lowry et al. (1951), based on the results of Bensadoun and Weinstein (1976) and Hess et al. (1978). Dried samples were hydrolyzed with a volume of $2.5 \mathrm{~N} \mathrm{NaOH}$ at $56^{\circ} \mathrm{C}$ for $30 \mathrm{~min}$ and then maintained $24 \mathrm{~h}$ at room temperature. Bovine serum albumin, which underwent the same treatment as the samples, was used as a standard. Total carbohydrates were quantified by the anthrone method described by Fraga (1956), with glucose as a standard. Dried samples were sonicated in $2 \mathrm{~mL}$ of $2 \mathrm{~N} \mathrm{KOH}$ and then hydrolyzed in a bath at $90^{\circ} \mathrm{C}$ for $60 \mathrm{~min}$.

The neutral and polar lipids were separated by micro-column liquid chromatography as described by Marty et al. (1992). Total lipids were evaporated to dryness and dissolved three times using $500 \mu \mathrm{L}$ of chloroform/methanol (98:2). Neutral (NL) and polar lipids (PL) were separated on a silica gel 6\% (w/w) hydrated microcolumn (30x5 mm) using chloroform/methanol (98:2) and methanol successively as eluting solvents. The fractions were collected under nitrogen in a screw-capped flask containing a known amount of 23:0 as internal standard for quantitative determinations. FAs from NL and PL fractions were transesterified with $10 \%(\mathrm{w} / \mathrm{w}) \mathrm{BF}_{3}$ in methanol for 10 min at $100^{\circ} \mathrm{C}$ (Metcalfe and Schmitz, 1961). After cooling, FA methyl esters were extracted with hexane. The organic phase was evaporated under nitrogen and dissolved in hexane for HPLC purification (Soudant et al., 1995). The FA composition and quantification of NL and PL were determined using gas chromatography (Variant, CP-3800), equipped with a fused silica capillary column (JW SCIEN, $30 \mathrm{~m}$ length, $0.25 \mathrm{~mm}$ i.d., $0.25 \mu \mathrm{m}$ film thickness), with a cool on-column injector at $63^{\circ} \mathrm{C}$. The carrier gas was $\mathrm{H}_{2}$, at an initial pressure of $80 \mathrm{kPa}$. The oven was programmed to stay at an initial temperature of $60^{\circ} \mathrm{C}$ for $2 \mathrm{~min}$, 
increase from 60 to $160^{\circ} \mathrm{C}$ at a rate $50^{\circ} \mathrm{C} \mathrm{min}{ }^{-1}$, stay there for $2 \mathrm{~min}$, then increase from 160 to $170^{\circ} \mathrm{C}$ at $1.5^{\circ} \mathrm{C} \mathrm{min}{ }^{-1}$, then from 170 to $185^{\circ} \mathrm{C}$ at $2^{\circ} \mathrm{C} \min ^{-1}$, then from $185-240^{\circ} \mathrm{C}$ at $3^{\circ} \mathrm{C} \mathrm{min}^{-1}$, and finally remain at $240^{\circ} \mathrm{C}$. FAs were identified by comparing their retention times with those of standards. A response factor was calculated for each FA in order to perform quantitative analyses.

\subsection{Statistical analysis}

Group normality was initially evaluated using a Shapiro-Wilks test and then a one-way analysis of variance (ANOVA) for significant differences was performed using the SPSS® 15.0 software package. The homogeneity of variances was checked by means of the Barlett's test. When necessary, post hoc analyses with the LSD test were applied. Shell length values were log-transformed to normalize variance. Percentage data were arcsine-transformed to normalize variance (Sokal and Rohlf, 1995). Differences were considered statistically significant if $p \leq 0.05$. Correlations between shell size or survival of 22-day-old larvae with dietary and larval proximate biochemical and FA composition were examined by Pearson's correlation coefficients using SPSS $® 15.0$ software package as well.

\section{Results}

3.1. Larval growth and survival

Diets containing Chaetoceros (IPC, IP2C and C) led to the highest growth rates and greater length at settlement, whereas larvae fed with IP showed the lowest growth (ANOVA, F = 28.746, $d f=3$, $p \leq 0.001$ ) (Table 2). The highest survival was observed in larvae fed with diets containing Chaetoceros (IPC, IP2C and C), although no significant differences were found between the three of them, with survival rates ranging from 24.9 to $31.5 \%$ (Table 2). On the other hand, the lowest survival rate was detected in larvae fed with IP $(8.1 \%)$, which was significantly different from the aforementioned group (ANOVA, $\mathrm{F}=17.111, d f=3, p=0.000)$.

\subsection{Biochemical and fatty acid composition of the diets}


Significant differences were observed in the percentage of proteins (ANOVA, $\mathrm{F}=11.705, d f=3$, $p=0.000$ ) and total lipids in the diets (ANOVA, $\mathrm{F}=22.882, d f=3, p=0.000$ ) (Fig. 1A). Diets IP and IPC exhibited a higher proportion of total lipids, with significant differences with IP2C and C (ANOVA, $\mathrm{F}=22.882, d f=3, p<0.05)$. A significantly higher percentage of proteins was observed in IP2C and C compared to the other diets (ANOVA, $\mathrm{F}=11.705, d f=3, p<0.05$ ). No significant differences were found in carbohydrate percentages (ANOVA, $\mathrm{F}=2.880, d f=3, p>0.05$ ).

Table3 shows the FA composition of the four experimental diets. The diets containing I. galbana and P. lutheri (IPC, IP2C and IP) were characterized by the predominance of 14:0, 16:0, 16:1(n-7), 18:1(n-9), 18:4(n-3), EPA and DHA, which accounted for $79.6 \%, 80.2 \%$ and $84.2 \%$ of total FAs (TFAs) in IPC, IP2C and IP respectively.On the other hand, the main FAs found in the single diet C were 14:0, 16:1(n-7), EPA, 16:0 and 16:3(n-4), accounting for $73.1 \%$ of TFAs. It can be pinpointed that in the monospecies diet $\mathrm{C}$ the amount of linoleic $(18: 2(\mathrm{n}-6))($ ANOVA, $\mathrm{F}=46.476, d f=3, p<0.05)$ and linolenic acids $(18: 3(\mathrm{n}-3))($ ANOVA, $\mathrm{F}=8.240, d f=3, p<0.05)$, was much lower than in the other diets.

Percentages of total saturated (SFAs), monounsaturated (MUFAs) and polyunsaturated (PUFAs) fatty acids were not significantly different $(p>0.05)$ in the diets tested. Nevertheless, SFAs and MUFAs were higher in IP2C and C than in IPC and IP. Conversely, PUFAs in IP2C and C were lower than in the other diets. The highest n-3:n-6 ratio was found in IP (7.8), and the lowest was observed in C (3.0). Similarly, the highest 22:6/20:5 ratio was observed forIP and was three-fold compared to that found in C. It was also significantly different to the other diets (ANOVA, $\mathrm{F}=17.573, d f=3, p<0.05$ ). In addition to that, the highest 20:5/20:4 ratio was found in IP and it was five-fold higher than that of C.

\subsection{Biochemical and fatty acid composition of the larvae}

D-shaped larvae stored mainly proteins and total lipids (Fig. 1B). The highest percentage of proteins was observed on the larvae fed with $\mathrm{C}$ on day 22 , whereas the lowest was found in the larvae fed with IP (ANOVA, $\mathrm{F}=23.231, d f=3, p<0.05$ ). Contrary to that, the highest percentage of total lipids was observed on the larvae fed with IP, which were significantly different from the IPC-IP2C and C 
groups (ANOVA, $\mathrm{F}=56.426, d f=3, p<0.05$ ). No differences were exhibited in carbohydrate proportion between larvae fed with different diets (ANOVA, $\mathrm{F}=0.611, d f=3, p>0.05)$.

D-shaped larvae (day 2) preferentialy stored 16:0, 18:1(n-9), 16:1(n-7), 14:0 and EPA in NL (Table 4). FA composition in NL of 22-day-old larvae was clearly related to diet composition. At the end of the experiment, larvae fed with IPC and IP exhibited a higher proportion of 18:1(n-9), 18:2(n-6), 18:3(n-3), 18:4(n-3) and DHA in NL than larvae fed with IP2C and C. Conversely, larvae fed with IP2C and $C$ on day 22 showed a higher percentage of 14:0, 16:1(n-7), 18:1(n-7) and 16:3(n-4) than those fed with the other diets. Moreover, larvae fed with $\mathrm{C}$ on day 22 showed the highest percentage of AA (ANOVA, $\mathrm{F}=44.379, d f=3, p<0.05$ ). Diets IP and IPC led to a higher proportion of PUFAs and specially $\omega 3$ PUFAs in NL of the larvae. On the other hand, MUFAs and Non-methylene-interrupted dienoic FAs (NMIDs) were higher in the larvae fed with rich diatoms diets (IP2C and C) compared to the rest of the groups studied. The highest n-3:n-6, 22:6/20:5 and 20:5/20:4 ratios in NL were found in the larvae fed with IP.

D-shaped larvae (day 2) stored mainly 16:0, DHA, EPA, 18:0dma and 18:0 in PL (Table 5). At the end of the experiment, larvae fed with IP exhibited greater storage of DHA, 16:0, EPA, 18:0dma and 18:0 in PL. Conversely, diet C lead to a higher proportion of EPA, 18:0dma, 16:0, DHA and 22:2j in PL of the day-22 larvae. FA composition in PL of 22-day-old larvae reflected the FA profile of the diets. For instance, the high levels of DHA and 18:4(n-3) detected in IP were found in PL of the larvae fed with IP. Similarly, enrichment in EPA and 16:1(n-7) was observed in the larvae fed with C. Larvae fed with C were the only diet regime in which a higher proportion of EPA than DHA in PL was reported. Moreover, this diet led to a greater enrichment in 22:5(n-3) in PL of the larvae compared to the larvae fed with other diets. Despite there were no differences in the proportion of total SFAs, MUFAs and PUFAs in the diets (Table 3), their percentages in PL were different $(p<0.05)($ Table 5). Higher SFA (ANOVA, F = 135.825, $d f=3, p<0.05$ ) and PUFA (ANOVA, $\mathrm{F}=14.545, d f=3, p<0.05$ ) levels in PL were observed in larvae fed with IP and IPC, respectively.Higher n-3:n-6 (ANOVA, F = 49.176, $d f=3, p<0.05$ ), 22:6/20:5 (ANOVA, $\mathrm{F}=1136.938, d f=3, p<0.05)$ and 20:5/20:4 (ANOVA, $\mathrm{F}=236.030, d f=3, p<$ 0.05) ratios were observed in larvae fed with IP compared to the diets including $C$. muelleri.

Multi-species IPC diet led to a greater 18:2(n-6) (ANOVA, $\mathrm{F}=130.602, d f=3, p<0.05)$, 18:3(n-3) (ANOVA, F = 10.629, $d f=3, p<0.05)$ and 18:4(n-3) $($ ANOVA, $\mathrm{F}=8.579, d f=3, p<0.05)$ storage in NL of the larvae (ng FA $\mu \mathrm{g} \mathrm{sample}^{-1}$ ) compared to any of the other diets (Fig. 2). Larvae fed 
with IPC stored higher amounts of EPA per $\mu \mathrm{g}$ of sample in NL than the rest of the treatments (ANOVA, $\mathrm{F}=12.778, d f=3, p<0.05)$, whereas larvae fed with $\mathrm{C}$ on day 22 retained more EPA in PL than larvae fed with other diets (ANOVA, $\mathrm{F}=268.234, d f=3, p<0.05$ ). Larvae fed $\mathrm{C}$ showed the higher amount of AA and the lower accumulation of DHA in NL and PL compared to the larvae under the other diets tested.

The FAs that accounted for the highest gains in NL (expressed as percentage) of the larvae were the EPA, 14:0, 16:0 and 16:1(n-7) (Table 6). Moreover, DHA and 18:4(n-3) increased more in larvae fed with diets containing I. galbana and P. lutheri. In contrast, larvae fed with C preferentially retained AA and 18:1(n-7). In PL, the main fatty acid gains of the larvae were detected in DHA, 16:0, EPA, 18:0dma and 18:0 in all the larvae fed with diets containing I. galbana and P. lutheri. It should be noted that DHA accounted for the highest rise in proportion in larvae fed with IPC, IP2C and IP, whereas for larvae fed with $\mathrm{C}$ the main increase in PL was recorded in EPA. In addition to EPA, larvae fed with C preferentially retained 18:0dma, 16:0, 18:0 and 22:2NMI in PL. All the FAs in PL of larvae fed with IPC and IP2C increased. Conversely, the SFA 20:0 and the PUFA 18:4(n-3) in larvae fed with C decreased with respect to D-larvae.

3.4. Relationships between growth, survival, and biochemical and FA composition

Correlation analysis between shell size $(\mu \mathrm{m})$ or survival $(\%)$ of 22-day-old $R$. decussatus larvae with dietary ( $\mu \mathrm{g} / \mathrm{mg}$ sample) and larval (ng individual ${ }^{-1}$ ) proximate biochemical and FA composition revealed various positive and negative correlations (Table 7). Shell size was negatively related to dietary lipids and carbohydrates, and survival was also negatively related to dietary carbohydrates. Significant negative correlations between dietary FA and shell size were observed for 16:0, DHA and DPA. However, dietary AA was positively related to shell size. Protein content in the larvae was positively related to survival, whereas lipid content was negatively related to growth of the larvae. Several correlations were found in the NL and PL of the larvae. In the NL, the SFA 16:0 was negatively related to growth and survival, whereas AA was positively related to both larval performance parameters. Moreover, a negative correlation was observed between DHA and DPA in NL of the larvae and growth. Growth and survival was positively related to 18:0, AA, EPA, 22:2NMID and MUFAs in 
PL. In addition to that, 18:0dma in PL was also positively related to shell size, whereas for SFAs and PUFAs in PL positive correlations with survival were observed.

\section{Discussion}

\subsection{Effects of algal diet on larval performance}

Our study shows that $R$. decussatus larvae fed with IP exhibited the lowest growth rate, length at settlement and survival, whereas larvae fed with diets including $C$. muelleri alone or together with $I$. galbana and P. lutheri (C, IPC and IP2C) promoted higher growth and survival. Similarly, larvae of the sea scallop Placopecten magellanicus fed with the mixture of I. galbana and P. lutheri exhibited lower larval performance in terms of growth and competence than the diets including I. galbana and C. muelleri (Pernet and Tremblay, 2004). In addition to that, a mixture of I. galbana (clone T-Iso) and P. lutheri led to poor growth and survival, and failed to achieve competency in Crassostrea gigas larvae (Rico-Villa et al., 2006). The same authors also observed that when both prymnesiophytes were combined with the diatom Chaetoceros calcitrans forma pumilum, high larval performance was recorded. The removal of $C$. calcitrans from the larval diet of Mytilus galloprovincialis significantly increased mortality and lowered settlement success, however no differences in growth were observed (Pettersen et al., 2010). In contrast, Pecten maximus larvae fed with I. galbana (Clone T-Iso) or P. lutheri alone sustained a higher survival at competency and settlement, than larvae fed with $C$. calcitrans alone, which displayed the highest growth and the lowest settlement (Delaunay et al., 1993). In Likewise, $R$. decussatus larvae fed with $C$. calcitrans alone exhibited slightly higher growth rates and survival and lower percentage of foot than larvae fed with I. galbana (Clone T-Iso) alone (Matias et al., 2011). All species used in this study were in the size range reported to be efficiently ingested by mollusc larvae (i.e. 2-10 $\mu \mathrm{m}$ ) (Palmer and Williams, 1980). Microalgae may be a vector of total bacteria,particularly vibrio, to bivalve larval cultures. There were no significant differences of total heterotrophic bacteria between diet treatments (data not presented). No vibrios were found in any of the diets used as feed in the present study (data not presented). Consequently, we discard bacterial load as a factor influencing larval performance in our study. In the light of all the aforementioned, the effects of microalgal diet on larval performance seems to be speciesspecific and it may also be sensitive to algal culture conditions that may alter biochemical and FA composition. 


\subsection{Effects of biochemical and FA composition of the microalgae on biochemical and FA of the larvae}

The influence of microalgal biochemical and FA composition on larval development has been widely reported in bivalves (e.g. Brown et al. (1997); Robert and Trintignac (1997) and Webb and Chu (1982)). In our study, IP and IPC diets were richer in total lipids (proportion of total organic matter $(\mathrm{OM}))$, whereas diets IP2C and C showed a higher proportion of proteins. Despite protein in microalgae is a component that is rarely addressed in terms of larval performance, some studies have linked highprotein diets to improved larval growth and survival, as in C. gigas and Argopecten purpuratus (Uriarte et al., 2004; Utting, 1986). The larvae fed with the protein-rich diets (IP2C and C) exhibited high growth and survival, although the larvae fed with IPC (with a lower protein and higher lipid relative content) also exhibited high larval performance. Moreover, different protein relative content in the diets did not alter protein relative content in the larvae at the end of the experiment. However, protein relative content $(\%$ $\mathrm{OM}$ ) of the larvae is positively related to larval survival.

There seems to be a negative correlation between the lipid content (\% OM) of the the diet and the lipid accumulation in $R$. decussatus larvae on day 22. The lower percentage of lipids in diet $\mathrm{C}$ led to a lower lipid accumulation in the larvae fed with this diet, although a high performace was observed in those larvae. On the contrary, larvae fed with IP stored a higher relative content of total lipids (\% OM) than larvae fed with other diets, exhibibiting lower growth and survival . In addition to that, a negative relationship was revealed between the percentage of total lipids of the diets (\% OM) and growth of the larvae. This may suggest that the proportion of total lipids in the diet is not a good indicator of larval survival in $R$. decussatus larvae, and that quantities and/or proportion of specific lipid compounds may explain differences in larval survival, since EFAs appear to be a limiting factor. High lipid diets fed to larval A. purpuratus (Nevejan et al., 2003) and P. maximus (Delaunay et al., 1993) both resulted in poor growth when EPA and DHA were absent.

Literature of bivalve larval development has not focused in dietary carbohydrates to a great extent. Many authors have suggested that carbohydrates do not play an important role during larval development in bivalves (Gallager et al., 1986; Holland and Spencer, 1973). In contrast, Whyte et al. (1989) pointed out that dietary carbohydrates may play an important role in bivalves in balancing the usage of protein and lipids for biosynthesis against their catabolism for energy production. Despite the 
fact that some authors have emphasized the importance of high-carbohydrate content microalgae for larval growth, such as Utting (1986) in C. gigas and Whyte et al. (1989) in Patinopecten yessoensis, our results showed a negative correlation between growth and survival, and the relative content of dietary carbohydrates $(\% \mathrm{OM})$. Nonetheless, carbohydrate proportion of the larvae (\% OM) was not correlated to either larval growth or survival.

C. muelleri provided high levels of EPA and low levels of DHA. Dietary DHA (expressed in \% of TFA) and DHA in NL (expressed in $n g \operatorname{larva}^{-1}$ ) of the larvae were negatively related to growth of the larvae. Contrary to that, EPA content in PL of the larvae (ng larva ${ }^{-1}$ ) was positively related to growth and survival. Rico-Villa et al. (2006) reported optimun values of EPA contained in the larvae (7-17\% of TFA) and DHA (7-14 \% TFA in the larvae) for a good larval development in C. gigas. Our results suggested that EPA should be more important (15-20\% of TFA in the larvae) than DHA (4-11\% of TFA in the larvae) for a good larval performance in R. decussatus (data not presented). This is consistent with the correlations of EPA and DHA with larval performance presented in this study. DHA accumulation in PL in larvae fed with diets with low DHA levels may be compensated by retention of other FAs, such as EPA, as observed in the present study. P. maximus larvae fed with $C$. calcitrans showed no apparent negative effects on growth but fewer pediveliger settlement (Delaunay et al., 1993). Moreover, dietary and larval EPA in P. magellanicus positively influenced larval growth (Pernet et al., 2005). Nonetheless, Fernández-Reiriz et al. (2011) highlighted that Venerupis pullastra larvae fed with T. suecica, a DHA deficient diet, exhibited low growth and high mortality.

The content of AA in $R$. decussatus larvae clearly reflects that provided by the diet. The presence of $C$. muelleri in the diet enhanced the accumulation of AA in NL and PL of clam larvae (Table 5). The single diet C contained $2.3 \%$ of AA (\% of TFA) compared to the AA-deficient diet IP $(0.3 \%)$. Increasing proportion of dietary AA led to higher growth of clam larvae (correlation coefficient $0.879(\mathrm{n}=8)$, table 6). In addition to that, AA content in NL and PL of the 22-day-old larvae (ng larva ${ }^{-1}$ ) was positively related to growth, and a higher level of AA accumulated in membrane lipids also corresponded to a higher survival of $R$. decussatus larvae. The importance of AA in invertebrate species is due to its role in eicosanoid production and stress response (Howard and Stanley, 1999). Several studies have suggested the detrimental effects of AA deficiency for survival and resistence to pathogens (Pernet et al., 2005). For example, low survival and growth of $P$. magellanicus larvae was observed under a diet low in AA 
$(0.41 \%)$ (Pernet and Tremblay, 2004). Moreover, AA play a role in enhancing growth in $M$.

galloprovincialis larvae (Pettersen et al., 2010) and P. magellanicus postlarvae (Milke et al., 2008).

In larvae fed with $\mathrm{C}$, a higher accumulation of 22:5(n-3) in PL was observed (Table 5), and consequently, a higher percentage was recorded in their PL, although this FA was not present in any of the diets. The fatty acid 22:5(n-3) was selectively incorporated as phosphatidylcholine in the male gonads of $P$. maximus (Soudant et al., 1997). These authors suggested an endogenous origin for the 22:5(n-3), biosynthesized by elongation from EPA, which has also been reported in fish larvae (Watanabe et al., 1989). This elongation process could contribute to rectifying the dietary deficiency in DHA with a FA having the nearest structure (Soudant et al., 1997). Larvae fed with C, a diet rich in EPA, may allocate part of the ingested EPA for its conversion into 22:5(n-3), as suggested by Soudant et al. (1997), and/or may regulate EPA levels as a strategy to avoid competition for eicosanoid production derived from AA, due to the lower activity of the homologues generated from EPA.

DPA was not found in NL and in low levels in PL of the larvae fed with C (Tables 3 and 4) due to the low levels in this diet. An inverse relationship between growth and both dietary DPA and DPA of NL of $R$. decussatus larvae was found in our study. Accumulation of DPA was reported in PL of larval $P$. maximus (Delaunay et al., 1993) and P. magellanicus (Pernet et al., 2005), thus, suggesting a specific role for this FA in cell membranes. DPA may serve a homologous functional role to DHA in PL with possible effects on transmembrane protein function (Pernet et al., 2005). Conversely, it may seem that in $R$. decussatus larvae DPA does not play the latter role since the larvae with lower DHA levels (fed with C) are those with lower DPA levels in PL.

The dimethyl acetal 18:0dma was found in high proportions and was greatly accumulated in PL of the larvae fed with C (Table 5). This compound originates from transmethylation of 1-alkenyl chains of plasmalogens, a type of ether-containing phosphoglycerides found in animal membrane cells. The abundance of plasmalogens in molluscs has been previously reported (Joseph, 1982; Kraffe et al., 2004). Nevertheless, information concerning their biologic function is still limited. These plasmalogens are thought to play a role as membrane components and some -ether-linked lipids seem to serve as protectice storage sites for PUFAs. The low proportion of DHA in PL in the larvae fed with C may partially explain the enrichment of 18:0dma in PL in order to modulate membrane dynamics. In fact, this FA is the one that exhibited the second greatest increase in PL of larvae fed with $\mathrm{C}$ (2.8 ng individual ${ }^{-1}$, Table 5), whereas in the other diets its incorporation in membranes ranged between 0.9 and $1.8 \mathrm{ng}$ individual $^{-1}$ 
(fourth greater increase in PL). Therefore, it highlights the importance of 18:0dma in the PL of $R$. decussatus larvae irrespective of the diet supplied. Moreover, the FA 18:0dma in PL (ng larva ${ }^{-1}$ ) of the larvae is positively related to growth of the larvae. In agreement with our results, the quantitatively most important dimethyl acetal in Ruditapes philippinarum (Caers et al., 1999a), A. purpuratus (Caers et al., 1999b; c) and C. gigas (Caers et al., 2000) is also 18:0dma.

Our results showed low levels of NMIDs in NL and high levels in PL of $R$. decussatus larvae (7.4-10.7\% of TFAs in PL), with very low levels of 20:2NMID compared to 22:2NMID. Higher levels of 22:2NMID (\% of TFA) were observed in the larvae fed with diets containing C. muelleri (C, IPC and IP2C), with maximum levels in larvae fed with $\mathrm{C}$. This may be related to the decreasing DHA levels in the larvae fed with increasing proportions of the deficient DHA diatom C. muelleri. In the larvae of the razor clam Solen marginatus, an inverse relationship between the levels of 22:2NMID and the major PUFAs, EPA and DHA has also been observed (da Costa et al., 2011). Similarly, Klingensmith (1982) pointed out the same trend in the tissues of the hard clam Mercenaria mercenaria. In our study, EPA was not related to NMIDs levels since larvae fed with C exbibited the highest levels of both EPA and NMIDs. Contrary to the low capability to synthesize PUFAs in bivalves (Delaunay et al., 1993; Laing et al., 1990), NMIDs are synthesized de novo in bivalves by elongation and $\Delta 5$ desaturation of $16: 1(\mathrm{n}-7)$ and $18: 1(\mathrm{n}-$ 9), which are abundant in phytoplankton, particularly diatoms (Zhukova, 1991). Similarly, Caers et al. (1999a) reported that $R$. philippinarum spat actively synthesized NMIDs irrespective of the diet supplied. In our study, all diets provided high levels of the precursors 16:1(n-7) and 18:1(n-9) (the sum of both was 18-20\% of TFA in the diets) for NMID production. However, larvae fed with diets containing C. muelleri (C, IPC and IP2C) incorporated 2-fold more 22:2NMIDs in their membranes than larvae fed with IP (2 vs. $1.1 \mathrm{ng}$ individual ${ }^{-1}$ ). Although little is known about NMID function, numerous studies have agreed on their structural and functional role in biological membranes (Klingensmith, 1982; Paradis and Ackman, 1977; Pirini et al., 2007). Kraffe et al. (2004) proposed important membrane properties for the NMI fatty acids such as phase transition temperature, membrane fluidity, or activity of membrane-bound proteins. It may also suggest that NMIDs in $R$. decussatus larvae were increased when certain PUFAs are deficient (i.e. DHA in larvae fed with diets including $C$. muelleri). Moreover, in our study a positive correlation was found between 22:2NMIDs in PL of the larvae (ng larva ${ }^{-1}$ ) and larval performance (i.e. growth and survival), thus suggesting the importance of these FAs in R. decussatus larvae. Similarly, FernándezReiriz et al. (2011) pinpointed a significant role for NMIDs in determining the weight of $V$. pullastra 
larvae. In addition to that, NMIDs are also important for starved S. marginatus larvae (da Costa et al., 2012). Moreover, as suggested for the latter authors, S. marginatus larvae seem to be genetically driven to biosynthesize NMIDs during larval development irrespective of the precursors provided by the diet, appearing in high levels in both NL and PL.

In summary, this study highlights the importance of diet composition in $R$. decussatus larval development and that diets may include C. muelleri. In our experiment, we have used this species of diatom, but it may be possible that other diatoms may fulfil clam larval nutritional needs. Further nutritional studies of $R$. decussatus larval stages should be carried out in order to improve (1) our knowledge of clam larval nutrition and (2) larval performance. Proximate biochemical composition highly influences larval performance, as increasing lipid and carbohydrate contents of the diets may reduce larval growth and survival. Moreover, this study also demonstrated that DHA deficiencies in the diet may not have deleterious effects on larval development, since clam larvae were able to modulate membrane composition by increasing the proportion of EPA, 18:0dma, 22:5(n-3) and 22:2NMIDs in PL. In addition to that, our findings suggest the importance of dietary AA and larval AA in NL and PL for $R$. decussatus larvae due to their positive relationship to growth and/or survival.

\section{Acknowledgements}

This research was funded by Junta Asesora Nacional de Cultivos Marino (JACUMAR). We are grateful to the staff of Centro de Cultivos Marinos de Ribadeo-CIMA (Xunta de Galicia). J.A. ArandaBurgos was funded by a Consellería do Mar-Xunta de Galicia fellowship. Fiz da Costa was partly supported by a Fundación Juana de Vega postdoctoral fellowship at IFREMER. The authors also wish to thank Dr Ceres Fernández-Rozadilla (University of Oxford) for improving the English version of the manuscript.

\section{References}

Albentosa, M., Pérez-Camacho, A., Labarta, U., Fernández-Reiriz, M.J., 1996. Evaluation of live microalgal diets for the seed culture of Ruditapes decussatus using physiological and biochemical parameters. Aquaculture 148, 11-23. 
Albentosa, M., Pérez-Camacho, A., Labarta, U., Fernández-Reiriz, M.J., 1997. Evaluation of freeze-dried microalgal diets for the seed culture of Ruditapes decussatus using physiological and biochemical parameters. Aquaculture 154, 305-321.

Barlett, B.R., 1979. Biochemical changes in the Pacific oyster, Crassostrea gigas (Thunberg) during larval development and metamorphosis. Procceedings of the National Shellfisheries Association $69,202$.

Beiras, R., Albentosa, M., 2004. Inhibition of embryo development of the commercial bivalves Ruditapes decussatus and Mytilus galloprovincialis by trace metals; implications for the implementation of seawater quality criteria. Aquaculture 230, 205-213.

Bensadoun, A., Weinstein, D., 1976. Assay of proteins in the presence of interfering material. Analytical biochemistry 70, 241-250.

Bligh, W.J., Dyer, W.J., 1959. A rapid method of total lipid extraction and purification. Canadian Journal of Biochemistry and Physiology 37, 911-917.

Brown, M.R., 2002. Nutritional value and use of microalgae in aquaculture. Avances en Nutrición Acuícola VI. Memorias del VI Simposium Internacional de Nutrición Acuícola 3, 281-292.

Brown, M.R., Jeffrey, S.W., Volkman, J.K., Dunstan, G.A., 1997. Nutritional properties of microalgae for mariculture. Aquaculture 151, 315-331.

Caers, M., Coutteau, P., Sorgeloos, P., 1999a. Dietary impact of algal and artificial diets, fed with at different feeding rations, on the growth and fatty acid composition of Tapes philippinarum (L.) spat. Aquaculture 170, 307-322.

Caers, M., Coutteau, P., Sorgeloos, P., 2000. Incorporation of different fatty acids, supplied as emulsions or liposomes, in the polar and neutral lipids of Crassostrea gigas spat. Aquaculture 186, 157 171.

Caers, M., Coutteau, P., Cure, K., Morales, V., Gajardo, G., Sorgeloos, P., 1999b. The Chilean scallop Argopecten purpuratus (Lamarck, 1819):I. Fatty acid composition and lipid content of six organs. Comparative Biochemistry and Physiology - Part B: Biochemistry and Molecular Biology 123, 89-96.

Caers, M., Coutteau, P., Cure, K., Morales, V., Gajardo, G., Sorgeloos, P., 1999c. The Chilean scallop Argopecten purpuratus (Lamarck, 1819): II. manipulation of the fatty acid composition and lipid 
content of the eggs via lipid supplementation of the broodstock diet. Comparative Biochemistry and Physiology - Part B: Biochemistry and Molecular Biology 123, 97-103.

Chu, F.-L.E., Greaves, J., 1991. Metabolism of palmitic, linoleic, and linolenic acids in adult oysters, Crassostrea virginica. Marine Biology 110, 229-236.

da Costa, F., Nóvoa, S., Ojea, J., Martínez-Patiño, D., 2011. Changes in biochemical and fatty acid composition of the razor clam Solen marginatus (Solenidae: Bivalvia) during larval development. Marine Biology 158, 1829-1840.

da Costa, F., Ojea, J., Nóvoa, S., Martínez-Patiño, D., 2012. Effects of algal diets and starvation on growth, survival and fatty acid composition of Solen marginatus (Bivalvia: Solenidae) larvae. Scientia Marina 76, 527-537.

Delaunay, F., Marty, Y., Moal, J., Samain, J.F., 1993. The effect of monospecific algal diets on growth and fatty acid composition of Pecten maximus (L.) larvae. Journal of Experimental Marine Biology and Ecology 173, 163-179.

FAO, 2010. Fishstat - FAO Fisheries Department, Fishery Information, Data and Statistics Unit.

Farrar, S., 1975. Low risk oyster culture in Spain. Fish Farming International 2, 29-39.

Fernández-Reiriz, M.J., Labarta, U., Albentosa, M., Pérez-Camacho, A., 1998. Effect of Microalgal Diets and Commercial Wheatgerm Flours on the Lipid Profile of Ruditapes decussatus Spat. Comparative Biochemistry and Physiology - Part A: Molecular \& Integrative Physiology 119, 369-377.

Fernández-Reiriz, M.J., Labarta, U., Albentosa, M., Pérez-Camacho, A., 1999. Lipid profile and growth of the clam spat, Ruditapes decussatus (L), fed with microalgal diets and cornstarch. Comparative Biochemistry and Physiology - Part B: Biochemistry and Molecular Biology 124, 309-318.

Fernández-Reiriz, M.J., Pérez-Camacho, A., Peteiro, L.G., Labarta, U., 2011. Growth and kinetics of lipids and fatty acids of the clam Venerupis pullastra during larval development and postlarvae. Aquaculture Nutrition 17, 13-23.

Fernández, A., García, T., Asensio, L., Rodríguez, M.A., González, I., Cespedes, A., Hernandez, P.E., Martin, R., 2000. Identification of the clam species Ruditapes decussatus (grooved carpet shell), Venerupis pullastra (pullet carpet shell), and Ruditapes philippinarum (Japanese carpet shell) by PCR-RFLP. Journal of Agricultural and Food Chemistry 48, 3336-3341. 
Fraga, F., 1956. Determinación de glucógeno en moluscos con el reactivo de la antrona. Investigaciones Pesqueras 3, 69-74. (In Spanish).

Gallager, S.M., Mann, R., Sasaki, G.C., 1986. Lipid as an index of growth and viability in three species of bivalve larvae. Aquaculture 56, 81-103.

Haws, M.C., DiMichele, L., Hand, S.C., 1993. Biochemical changes and mortality during metamorphosis of the Eastern Oyster, Crassostrea virginica, and the Pacific oyster, Crassostrea gigas.

Molecular Marine Biology and Biotechnology 2, 207-217.

Helm, M.M., Holland, D.L., Stephenson, R.R., 1973. The effect of supplementary algal feeding of a hatchery and breeding stock of Ostrea edulis L. on larval vigour. Journal of the Marine Biological Association of the United Kingdom 53, 673-684.

Helm, M.M., Bourne, N., Lovatelli, A., 2004. Hatchery operation: Broodstock conditioning, spawning and fertilization. In: Lovatelli, A. (Ed.), Hatchery culture of bivalves. A practical manual. FAO Fish. Tech. Paper, Rome, pp. 59-83.

Hendriks, I.E., van Duren, L.A., Herman, P.M.J., 2003. Effect of dietary polyunsaturated fatty acids on reproductive output and larval growth of bivalves. Journal of Experimental Marine Biology and Ecology 296, 199-213.

Hess, H.H., Lees, J.E., Derr, J.E., 1978. A linear Lowry-Folin assay for both water-soluble and sodium dodecyl sulfate-solubilized proteins. Analytical Biochemistry 85, 259-300.

Holland, D.L., Spencer, B.E., 1973. Biochemical changes in fed with and starved oysters, Ostrea edulis (L.) during larval development, metamorphosis and early spat growth. Journal of the Marine Biological Association of the United Kingdom 53, 287-298.

Howard, R.W., Stanley, D.W., 1999. The tie that binds: Eicosanoids in invertebrate biology. Annals of the Entomological Society of America 92, 880-890.

Joseph, J.D., 1982. Lipid composition of marine and estuarine invertebrates. Part II: Mollusca. Progress in Lipid Research 21, 109-153.

Klingensmith, J., 1982. Distribution of methylene and nonmethylene-interrupted dienoic fatty acids in polar lipids and triacylglycerols of selected tissues of the hardshell clam (Mercenaria mercenaria). Lipids 17, 976-981.

Kraffe, E., Soudant, P., Marty, Y., 2004. Fatty acids of serine, ethanolamine, and choline plasmalogens in some marine bivalves. Lipids 39, 59-66. 
Laing, I., Child, A.R., Janke, A., 1990. Nutritional value of dried algae diets for larvae of Manila clam (Tapes philippinarum). J. Mar. Biol. Assoc. U.K. 70, 1-12.

Lowry, O.H., Rosebrough, N.J., Farr, A.L., Randall, R.J., 1951. Protein measurement with the Folin fenol reagent. Journal of Biological Chemistry 193, 265-275.

Marsh, J.B., Weinstein, D.B., 1966. Simple charring method for determination of lipids. Journal of Lipid Research 7, 574-576.

Marshall, R., McKinley, S., Pearce, C.M., 2010. Effects of nutrition on larval growth and survival in bivalves. Reviews in Aquaculture 2, 33-55.

Marty, Y., Delaunay, F., Moal, J., Samain, J.F., 1992. Changes in the fatty acid composition of Pecten maximus (L.) during larval development. Journal of Experimental Marine Biology and Ecology $163,221-234$.

Matias, D., Joaquim, S., Ramos, M., Sobral, P., Leitão, A., 2011. Biochemical compounds’ dynamics during larval development of the carpet-shell clam Ruditapes decussatus (Linnaeus, 1758): effects of mono-specific diets and starvation. Helgoland Marine Research 65, 369-379.

Metcalfe, L.D., Schmitz, A.A., 1961. The rapid preparation of fatty acid esters for gas chromatography analysis. Analytical Chemistry 33, 363-364.

Milke, L.M., Bricelj, V.M., Parrish, C.C., 2008. Biochemical characterization and nutritional value of three Pavlova spp. in unialgal and mixed diets with Chaetoceros muelleri for postlarval sea scallops, Placopecten magellanicus. Aquaculture 276, 130-142.

Nevejan, N., Saez, I., Gajardo, G., Sorgeloos, P., 2003. Supplementation of EPA and DHA emulsions to a Dunaliella tertiolecta diet: effect on growth and lipid composition of scallop larvae, Argopecten purpuratus (Lamarck, 1819). Aquaculture 217, 613-632.

Ojea, J., Pazos, A.J., Martinez, D., Novoa, S., Garcia-Martinez, P., Sanchez, J.L., Abad, M., 2008. Effects of temperature regime on broodstock conditioning of Ruditapes decussatus. Journal of Shellfish Research 27, 1093-1100.

Palacios, E., Racotta, I.S., Kraffe, E., Marty, Y., Moal, J., Samain, J.F., 2005. Lipid composition of the giant lion's-paw scallop (Nodipecten subnodosus) in relation to gametogenesis: I. Fatty acids. Aquaculture 250, 270-282.

Palmer, R.E., Williams, L.G., 1980. Effect of particle concentration on filtration efficiency of the bay scallop Argopecten irradians and the oyster Crassostrea virginica. Ophelia 19, 163-174. 
Paradis, M., Ackman, R., 1977. Potential for employing the distribution of anomalous non-methyleneinterrupted dienoic fatty acids in several marine invertebrates as part of food web studies. Lipids 12, 170-176.

Pérez-Camacho, A., Albentosa, M., Fernández-Reiriz, M.J., Labarta, U., 1998. Effect of microalgal and inert (cornmeal and cornstarch) diets on growth performance and biochemical composition of Ruditapes decussatus seed. Aquaculture 160, 89-102.

Pernet, F., Tremblay, R., 2004. Effect of varying levels of dietary essential fatty acid during early ontogeny of the sea scallop Placopecten magellanicus. Journal of Experimental Marine Biology and Ecology 310, 73-86.

Pernet, F., Bricelj, V.M., Parrish, C.C., 2005. Effect of varying dietary levels of omega 6 polyunsaturated fatty acids during the early ontogeny of the sea scallop, Placopecten magellanicus. Journal of Experimental Marine Biology and Ecology 327, 115-133.

Pernet, F., Tremblay, R., Demers, E., Roussy, M., 2003. Variation of lipid class and fatty acid composition of Chaetoceros muelleri and Isochrysis sp. grown in a semicontinuous system. Aquaculture 221, 393-406.

Persoone, G., Claus, C., 1980. Mass culture of algae: a bottleneck in the nursery culturing of molluscs. Algae Biomass. Elsevier/North-Holland Biomedical Press, Amsterdam, 265-285.

Pettersen, A.K., Turchini, G.M., Jahangard, S., Ingram, B.A., Sherman, C.D.H., 2010. Effects of different dietary microalgae on survival, growth, settlement and fatty acid composition of blue mussel (Mytilus galloprovincialis) larvae. Aquaculture 309, 115-124.

Pirini, M., Manuzzi, M.P., Pagliarani, A., Trombetti, F., Borgatti, A.R., Ventrella, V., 2007. Changes in fatty acid composition of Mytilus galloprovincialis (Lmk) fed with on microalgal and wheat germ diets. Comparative Biochemistry and Physiology - Part B: Biochemistry and Molecular Biology 147, 616-626.

Rico-Villa, B., Le Coz, J.R., Mingant, C., Robert, R., 2006. Influence of phytoplankton diet mixtues on microalgae consumption, larval development and settlement of the Pacific oyster Crassostrea gigas (Thunberg). Aquaculture 256, 377-388.

Robert, R., Trintignac, P., 1997. Microalgues et nutrition larvaire en écloserie de mollusques. Haliotis 26, 1-13. (In French). 
Rodriguez, J.L., Sedano, F.J., Garcia Martin, L.O., Perez Camacho, A., Sanchez, J.L., 1990. Energy metabolism of newly settled Ostrea edulis spat during metamorphosis. Marine Biology 106, 109-111.

Sokal, R.R., Rohlf, F.J., 1995. Biometry. The principles and practice of statistics in biological research. Freeman, New York, 358 pp.

Soudant, P., Marty, Y., Moal, J., Samain, J.F., 1995. Separation of major polar lipids in Pecten maximus by high-performance liquid chromatography and subsequent determination of their fatty acids using gas chromatography Journal of Chromatography B: Biomedical Applications 673, 15-26.

Soudant, P., Moal, J., Marty, Y., Samain, J.F., 1997. Composition of polar lipid classes in male gonads of Pecten maximus (L) - Effect of nutrition. Journal of Experimental Marine Biology and Ecology 215, 103-114.

Uriarte, I., Farías, A., Hernandez, J., Schäfer, C.S., P., 2004. Reproductive conditioning of Chilean scallop (Argopecten purpuratus) and the Pacific oyster (Crassostrea gigas): effects of enriched diets. Aquaculture 230, 349-357.

Utting, S.D., 1986. A preliminary study on growth of Crassostrea gigas larvae and spat in relation to dietary protein. Aquaculture 56, 123-138.

Vela, J.M., Moreno, O., 2005. Pérfil bio-ecológico de la almeja fina (Tapes decussatus (Linneo, 1758)). In: Morales, J., Mata, A.J., Rodríguez, A. (Eds.), Acuicultura, pesca y marisqueo en el Golfo de Cádiz. Junta de Andalucía. Consejería de Agricultura y Pesca, Sevilla, pp. 641-662. (In Spanish).

Waldock, M.J., Holland, D.L., 1984. Fatty acid metabolism in young oysters, Crassostrea gigas: polyunsaturated fatty acids. Lipids 19, 332-336.

Watanabe, T., Izquierdo, M.S., Takeuchi, T., Satoh, S., Kitajima, C., 1989. Comparison between eicosapentaenoic and docosahexaenoic acids in terms of essential fatty acid efficacy in larval red seabream. Nippon Suisan Gakkai 55, 1635-1640.

Webb, K.I., Chu, F.E., 1982. Phytoplankton as a food source for bivalve larvae. In: Pruder, G.D., Langdon, C., Conklin, D. (Eds.), Proceedings of the second international conference on aquaculture nutrition; biochemical and physiological approaches to shellfish nutrition. Louisiana State University, Baton Rouge, Louisiana, USA, pp. 272-290.

Whyte, J.N.C., Bourne, N., Hodgson, C.A., 1989. Influence of algal diets on biochemical-composition and energy reserves in Patinopecten yessoensis (Jay) larvae. Aquaculture 78, 333-347. 
Yan, X., Zhang, G., Yang, F., 2006. Effects of diet, stocking density, and environmental factors on growth, survival, and metamorphosis of Manila clam Ruditapes philippinarum larvae.

Aquaculture 253, 350-358.

Zhukova, N.V., 1991. The pathway of the biosynthesis of non-methylene-interrupted dienoic fatty acids in molluscs. Comparative Biochemistry and Physiology - Part B: Comparative Biochemistry $100,801-804$. 


\section{Figure legends}

Fig. 1. A. Biochemical composition of the diets in percentage (expressed as mean \pm S.D. of organic matter). B. Biochemical composition of $R$. decussatus larvae in percentage (expressed as mean \pm S.D. of organic matter) on day 2 (d-shaped larvae) and on day 22 (settlement). C: diet C. muelleri; C-L22D: 22 day-old larvae fed with C; IP: I. galbana and P. lutheri (1:1); IP-L22D: 22 day-old larvae fed with diet IP; IPC: diet I. galbana, P. lutheri and C. muelleri (1:1:1); IPC-L22D: 22 day-old larvae fed with IPC; IP2C: diet I. galbana, P. lutheri and C. muelleri (1:1:2); IP2C-L22D: 22 day-old larvae fed with diet IP2C; LD: D-shaped larvae (day 2). Values with same letter for each biochemical component are not significantly different at $p>0.05$.

Fig. 2. Content in ng FA $\mu g$ sample $^{-1}$ of $A A(A), E P A(C)$ and DHA (E) and their precursors in neutral lipids, and content of AA (B), EPA (D) and DHA(F) and their precursors in polar lipids of R. decussatus larvae (expressed as mean \pm S.D.). Different superscript letters represent significant differences $(P<$ 0.05) of the same fatty acid between treatments. C-L22D: 22 day-old larvae fed with C; IP-L22D: 22 dayold larvae fed with diet IP; IPC-L22D: 22 day-old larvae fed with IPC; IP2C-L22D: 22 day-old larvae fed with diet IP2C; LD: D-shaped larvae (day 2). Values with same letter for each fatty acid are not significantly different at $p>0.05$. 


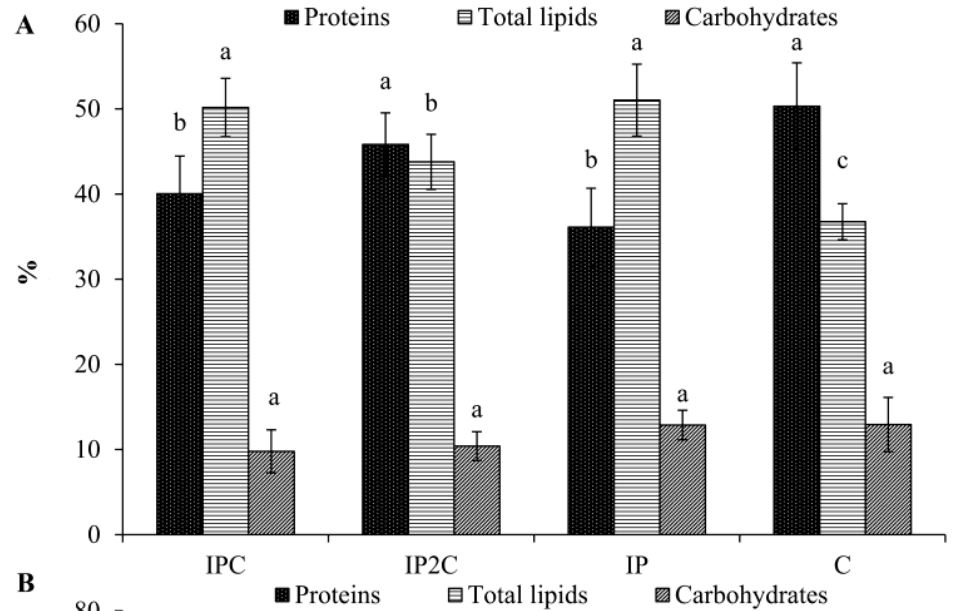

B

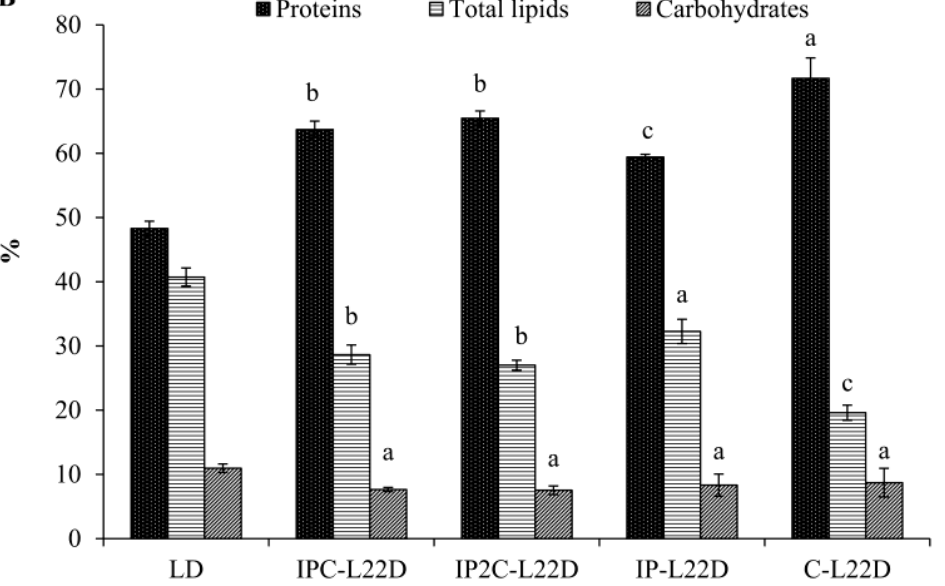

Figure 1 

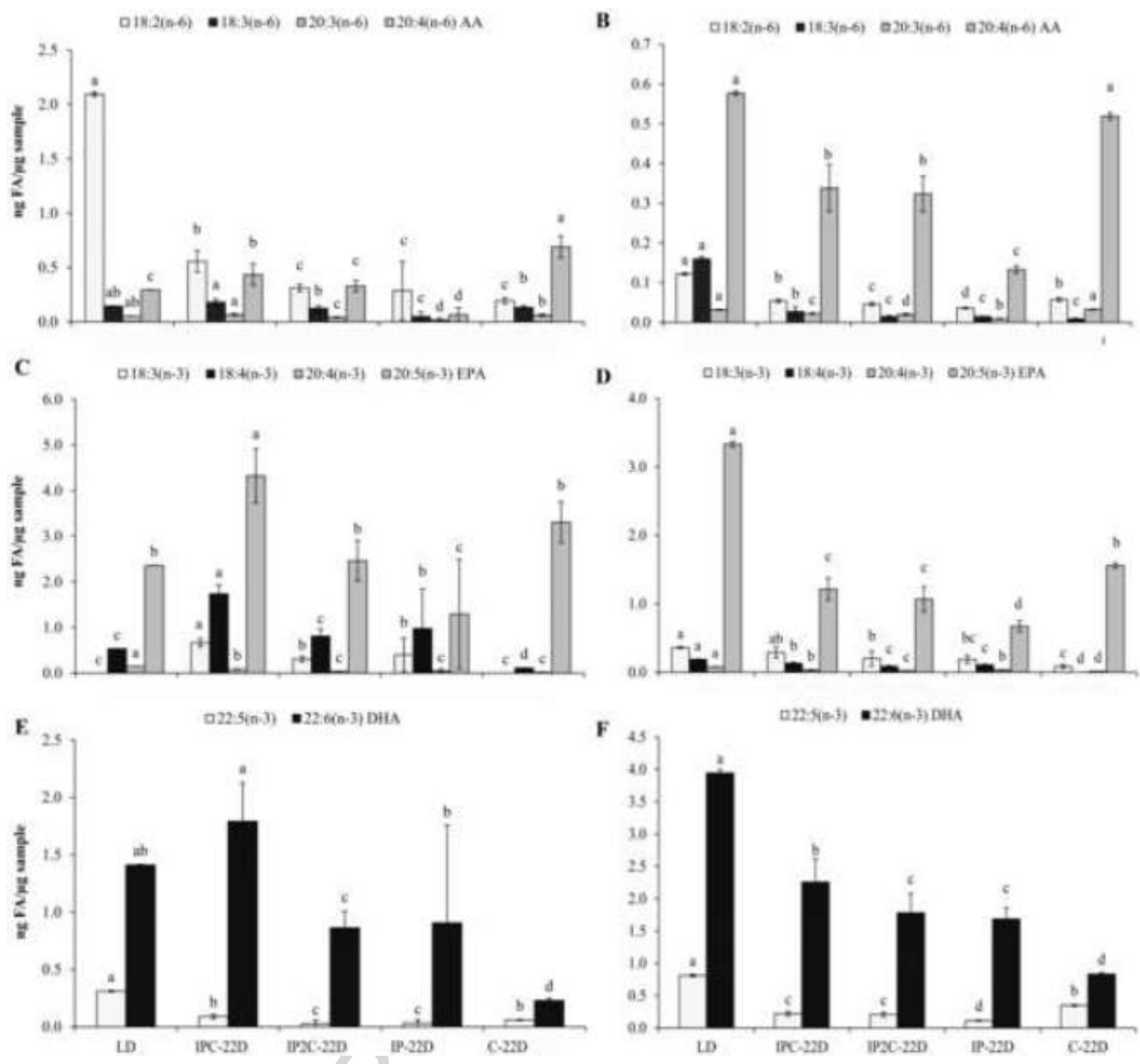

Figure 2 


\section{Table 1}

Evolution of daily food ration (total number of algal cells per microliter) related with larval age. C: diet C. muelleri; IP: I. galbana and P. lutheri (1:1); IPC: diet I. galbana, P. lutheri and C. muelleri (1:1:1); IP2C: diet I. galbana, P. lutheri and C. muelleri (1:1:2).

\begin{tabular}{ccccccccccccccccccccccccc}
\hline $\begin{array}{c}\text { Age of } \\
\text { larvae } \\
\text { (days) }\end{array}$ & 2 & 3 & 4 & 5 & 6 & 7 & 8 & 9 & 10 & 11 & 12 & 13 & 14 & 15 & 16 & 17 & 18 & 19 & 20 & 21 & 22 \\
\hline IPC & 40 & 60 & 60 & 60 & 60 & 60 & 60 & 60 & 60 & 60 & 70 & 70 & 70 & 70 & 70 & 70 & 70 & 70 & 70 & 70 & 70 \\
IP2C & 40 & 60 & 60 & 60 & 60 & 60 & 60 & 60 & 60 & 60 & 70 & 70 & 70 & 70 & 70 & 70 & 70 & 70 & 70 & 70 & 70 \\
IP & 40 & 60 & 60 & 60 & 60 & 60 & 60 & 60 & 60 & 60 & 70 & 70 & 70 & 70 & 70 & 70 & 70 & 70 & 70 & 70 & 70 \\
C & 40 & 60 & 60 & 60 & 60 & 60 & 60 & 60 & 60 & 60 & 70 & 70 & 70 & 70 & 70 & 70 & 70 & 70 & 70 & 70 & 70 \\
\hline
\end{tabular}




\section{Table 2}

Mean shell length (S.D.) and survival (S.D.) of Ruditapes decussatus larvae fed different mono- or multispecies diets. C: diet C. muelleri; IP: I. galbana and P. lutheri (1:1); IPC: diet I. galbana, P. lutheri and C. muelleri (1:1:1); IP2C: diet I. galbana, P. lutheri and C. muelleri (1:1:2).

\begin{tabular}{cccc}
\hline Diets & Shell length $(\mu \mathrm{m})$ & Survival $(\%)$ & Growth rate $\left(\mu \mathrm{m} \mathrm{d}^{-1}\right)$ \\
\hline IPC & $224 \pm 13^{\text {ab }}$ & $27 \pm 0^{\mathrm{a}}$ & 6.9 \\
IP2C & $217 \pm 21^{\mathrm{b}}$ & $32 \pm 0^{\mathrm{a}}$ & 6.7 \\
IP & $201 \pm 10^{\mathrm{c}}$ & $8 \pm 0^{\mathrm{b}}$ & 5.9 \\
C & $228 \pm 14^{\mathrm{a}}$ & $25 \pm 0^{\mathrm{a}}$ & 7.3 \\
\hline
\end{tabular}

Values with the same letters in the same column are not significant at $p>0.05$ 
Table 3

Fatty acid composition of total lipids of the diets (expressed as mean \pm S.D. of total fatty acid percentage). C: $\operatorname{diet}$ C. muelleri; IP: I. galbana and P. lutheri (1:1); IPC: diet I. galbana, P. lutheri and $C$. muelleri (1:1:1); IP2C: diet I. galbana, P. lutheri and C. muelleri $(1: 1: 2)$. Fatty acids representing less than $1 \%$ of total fatty acids were excluded from the list.

\begin{tabular}{|c|c|c|c|c|}
\hline & IPC & IP2C & IP & $\mathrm{C}$ \\
\hline 14:0 & $21.0 \pm 1.6^{\mathrm{ab}}$ & $21.5 \pm 6.9^{\mathrm{ab}}$ & $16.0 \pm 2.1^{b}$ & $26.0 \pm 5.3^{\mathrm{a}}$ \\
\hline $16: 0$ & $11.1 \pm 1.6^{\mathrm{a}}$ & $14.6 \pm 9.5^{\mathrm{a}}$ & $16.7 \pm 5.7^{\mathrm{a}}$ & $10.9 \pm 5.5^{\mathrm{a}}$ \\
\hline 18:0 & $1.2 \pm 0.5^{\mathrm{a}}$ & $1.8 \pm 1.8^{\mathrm{a}}$ & $1.6 \pm 1.3^{\mathrm{a}}$ & $1.9 \pm 1.1^{\mathrm{a}}$ \\
\hline $16: 1(n-7)$ & $12.2 \pm 0.8^{\mathrm{b}}$ & $12.1 \pm 3.0^{\mathrm{b}}$ & $\pm 1.7^{\mathrm{c}}$ & $16.6 \pm 3.9^{\mathrm{a}}$ \\
\hline $18: 1(n-9)$ & $6.3 \pm 1.6^{\mathrm{a}}$ & $7.8 \pm 5.7^{\mathrm{a}}$ & $11.2 \pm 7.9^{\mathrm{a}}$ & $3.5 \pm 2.0^{\mathrm{a}}$ \\
\hline $18: 1(n-7)$ & $1.6 \pm 0.2^{\mathrm{a}}$ & $2.2 \pm 0.3^{\mathrm{a}}$ & $1.5 \pm 0.3^{\mathrm{a}}$ & $2.6 \pm 1.2^{\mathrm{a}}$ \\
\hline $16: 2(n-7)$ & $0.9 \pm 0.4^{b}$ & $0.9 \pm 0.2^{\mathrm{b}}$ & $0.0 \pm 0.0^{\mathrm{c}}$ & $1.7 \pm 0.5^{\mathrm{a}}$ \\
\hline $16: 2(n-4)$ & $1.6 \pm 0.4^{\mathrm{a}}$ & $1.5 \pm 0.2^{\mathrm{a}}$ & $0.9 \pm 0.2^{b}$ & $1.7 \pm 0.2^{\mathrm{a}}$ \\
\hline $16: 3(n-6)$ & $0.9 \pm 0.2^{b}$ & $0.9 \pm 0.2^{\mathrm{b}}$ & $0.2 \pm 0.0^{\mathrm{c}}$ & $2.0 \pm 0.7^{\mathrm{a}}$ \\
\hline $16: 3(n-4)$ & $3.3 \pm 2.3^{\mathrm{a}}$ & $3.2 \pm 2.2^{\mathrm{a}}$ & $0.1 \pm 0.0^{b}$ & $5.2 \pm 0.7^{\mathrm{a}}$ \\
\hline $18: 2(n-6)$ & $3.0 \pm 0.9^{\mathrm{a}}$ & $2.4 \pm 0.2^{\mathrm{a}}$ & $3.1 \pm 0.3^{\mathrm{a}}$ & $1.4 \pm 0.3^{\mathrm{b}}$ \\
\hline $18: 3(n-6)$ & $1.1 \pm 0.2^{\mathrm{a}}$ & $1.0 \pm 0.3^{\mathrm{a}}$ & $0.7 \pm 0.3^{\mathrm{a}}$ & $1.5 \pm 0.5^{\mathrm{a}}$ \\
\hline $18: 3(n-3)$ & $3.6 \pm 1.6^{\mathrm{a}}$ & $3.0 \pm 1.9^{\mathrm{a}}$ & $4.6 \pm 2.0^{\mathrm{a}}$ & $0.8 \pm 1.2^{\mathrm{b}}$ \\
\hline $18: 4(n-3)$ & $10.0 \pm 3.3^{\mathrm{a}}$ & $8.6 \pm 4.7^{\mathrm{a}}$ & $13.7 \pm 4.7^{\mathrm{a}}$ & $3.6 \pm 4.1^{\mathrm{a}}$ \\
\hline $18: 5(n-3)$ & $1.4 \pm 0.5^{\mathrm{a}}$ & $1.2 \pm 0.6^{\mathrm{a}}$ & $1.7 \pm 0.4^{\mathrm{a}}$ & $0.5 \pm 0.7^{\mathrm{b}}$ \\
\hline $20: 4(n-6)$ AA & $1.1 \pm 0.1^{\mathrm{bc}}$ & $1.2 \pm 0.4^{\mathrm{b}}$ & $0.4 \pm 0.2^{\mathrm{c}}$ & $2.3 \pm 1.0^{\mathrm{a}}$ \\
\hline 20:5(n-3) EPA & $13.1 \pm 2.6^{\mathrm{a}}$ & $11.1 \pm 2.3^{\mathrm{a}}$ & $12.3 \pm 3.2^{\mathrm{a}}$ & $14.4 \pm 2.9^{\mathrm{a}}$ \\
\hline $22: 5(n-6)$ & $0.6 \pm 0.2^{\mathrm{a}}$ & $0.5 \pm 0.3^{\mathrm{a}}$ & $0.9 \pm 0.3^{\mathrm{a}}$ & $0.2 \pm 0.2^{\mathrm{a}}$ \\
\hline 22:6(n-3) DHA & $5.8 \pm 1.2^{\mathrm{a}}$ & $4.6 \pm 2.3^{\mathrm{a}}$ & $7.3 \pm 1.6^{\mathrm{a}}$ & $2.9 \pm 2.5^{\mathrm{a}}$ \\
\hline$\Sigma$ SAFA & $33.3 \pm 1.7^{\mathrm{a}}$ & $38.0 \pm 5.3^{\mathrm{a}}$ & $34.3 \pm 5.6^{\mathrm{a}}$ & $38.8 \pm 5.7^{\mathrm{a}}$ \\
\hline$\Sigma$ MUFA & $20.2 \pm 1.5^{\mathrm{a}}$ & $22.0 \pm 3.0^{\mathrm{a}}$ & $19.9 \pm 6.3^{\mathrm{a}}$ & $22.9 \pm 3.2^{\mathrm{a}}$ \\
\hline$\Sigma n-9$ & $6.3 \pm 1.6^{\mathrm{a}}$ & $7.8 \pm 5.7^{\mathrm{a}}$ & $11.4 \pm 7.9^{\mathrm{a}}$ & $3.7 \pm 2.0^{\mathrm{a}}$ \\
\hline$\Sigma \mathrm{n}-7$ & $13.9 \pm 0.8^{\mathrm{b}}$ & $14.2 \pm 2.8^{\mathrm{b}}$ & $8.5 \pm 1.6^{\mathrm{c}}$ & $19.2 \pm 4.7^{\mathrm{a}}$ \\
\hline$\Sigma$ PUFA & $46.5 \pm 2.2^{\mathrm{a}}$ & $40.0 \pm 7.9^{\mathrm{a}}$ & $45.8 \pm 11.8^{a}$ & $38.3 \pm 8.3^{\mathrm{a}}$ \\
\hline$\sum \mathrm{n}-4$ & $4.9 \pm 2.7^{\mathrm{a}}$ & $4.7 \pm 2.4^{\mathrm{a}}$ & $0.9 \pm 0.2^{b}$ & $7.0 \pm 0.7^{\mathrm{a}}$ \\
\hline$\Sigma \mathrm{n}-6$ & $6.8 \pm 1.1^{\mathrm{a}}$ & $6.1 \pm 1.3^{\mathrm{a}}$ & $5.2 \pm 0.9^{\mathrm{a}}$ & $7.4 \pm 1.7^{\mathrm{a}}$ \\
\hline$\sum n-3$ & $34.6 \pm 4.2^{\mathrm{a}}$ & $28.8 \pm 9.4^{\mathrm{a}}$ & $40.5 \pm 11.1^{\mathrm{a}}$ & $22.4 \pm 10.3^{\mathrm{a}}$ \\
\hline$n-3 / n-6$ & $5.1 \pm 0.0^{\mathrm{a}}$ & $4.7 \pm 0.0^{\mathrm{a}}$ & $7.8 \pm 0.0^{\mathrm{a}}$ & $3.0 \pm 0.0^{\mathrm{a}}$ \\
\hline $22: 6 / 20: 5$ & $0.4 \pm 0.0^{\mathrm{a}}$ & $0.4 \pm 0.0^{\mathrm{a}}$ & $0.6 \pm 0.0^{\mathrm{a}}$ & $0.2 \pm 0.0^{\mathrm{b}}$ \\
\hline $22: 5 / 20: 4$ & $0.6 \pm 0.0^{\mathrm{b}}$ & $0.4 \pm 0.0^{b}$ & $2.2 \pm 0.0^{\mathrm{a}}$ & $0.1 \pm 0.0^{c}$ \\
\hline $20: 5 / 20: 4$ & $11.5 \pm 0.0^{\mathrm{b}}$ & $9.1 \pm 0.0^{b}$ & $32.2 \pm 0.0^{\mathrm{a}}$ & $6.2 \pm 0.0^{\mathrm{b}}$ \\
\hline
\end{tabular}

Values with same letters in the same row are not significant at $p>0.05$. 
Table 4

Fatty acid composition of total neutral lipids of $R$. decussatus larvae (expressed as mean \pm S.D. of fatty acids of neutral lipids) on day 2 and on day 22 C: diet C. muelleri; IP: I. galbana and P. lutheri (1:1); IPC: diet I. galbana, P. lutheri and C. muelleri (1:1:1); IP2C: diet I. galbana, P. lutheri and C. muelleri (1:1:2). Fatty acids representing less than $1 \%$ of total fatty acids were excluded from the list.

\begin{tabular}{|c|c|c|c|c|c|}
\hline & Day 2 & Day 22-IPC & Day 22-IP2C & Day 22-IP & Day 22-C \\
\hline $14: 0$ & $8.3 \pm 0.0^{\mathrm{d}}$ & $13.9 \pm 0.5^{b c}$ & $16.6 \pm 0.3^{\mathrm{ab}}$ & $12.7 \pm 0.0^{c}$ & $17.6 \pm 1.6^{\mathrm{a}}$ \\
\hline $16: 0$ & $25.9 \pm 0.0^{\mathrm{a}}$ & $11.9 \pm 0.1^{\mathrm{b}}$ & $12.3 \pm 0.3^{b}$ & $15.0 \pm 0.6^{\mathrm{b}}$ & $10.8 \pm 1.2^{\mathrm{b}}$ \\
\hline 18:0 & $5.0 \pm 0.0^{\mathrm{a}}$ & $3.0 \pm 0.0^{\mathrm{a}}$ & $3.7 \pm 0.2^{\mathrm{a}}$ & $3.4 \pm 0.1^{\mathrm{a}}$ & $3.2 \pm 2.1^{\mathrm{a}}$ \\
\hline $16: 1(n-7)$ & $12.0 \pm 0.0^{\mathrm{ab}}$ & $9.0 \pm 0.2^{\mathrm{bd}}$ & $10.5 \pm 0.0^{b c}$ & $7.3 \pm 0.2^{\mathrm{d}}$ & $13.9 \pm 1.0^{\mathrm{a}}$ \\
\hline $18: 1(n-9)$ & $16.3 \pm 0.0^{\mathrm{a}}$ & $4.7 \pm 0.2^{b}$ & $4.5 \pm 0.2^{\mathrm{b}}$ & $6.2 \pm 0.3^{b}$ & $2.7 \pm 0.5^{b}$ \\
\hline $18: 1(n-7)$ & $5.5 \pm 0.0^{\mathrm{b}}$ & $5.3 \pm 0.0^{b}$ & $6.8 \pm 0.2^{\mathrm{a}}$ & $5.0 \pm 0.2^{b}$ & $8.2 \pm 0.5^{\mathrm{a}}$ \\
\hline $20: 1(n-11)$ & $1.3 \pm 0.0^{\mathrm{a}}$ & $0.2 \pm 0.0^{\mathrm{b}}$ & $0.2 \pm 0.0^{\mathrm{b}}$ & $0.2 \pm 0.0^{\mathrm{b}}$ & $0.2 \pm 0.1^{\mathrm{b}}$ \\
\hline $16: 2(n-4)$ & $0.0 \pm 0.0^{\mathrm{d}}$ & $0.9 \pm 0.0^{\mathrm{b}}$ & $1.0 \pm 0.0^{\mathrm{b}}$ & $0.5 \pm 0.0^{\mathrm{c}}$ & $1.5 \pm 0.1^{\mathrm{a}}$ \\
\hline $16: 3(n-4)$ & $0.0 \pm 0.0^{c}$ & $1.1 \pm 0.0^{\mathrm{b}}$ & $1.6 \pm 0.1^{\mathrm{b}}$ & $0.0 \pm 0.0^{c}$ & $3.4 \pm 0.2^{\mathrm{a}}$ \\
\hline $16: 3(n-3)$ & $0.7 \pm 0.0^{\mathrm{a}}$ & $0.0 \pm 0.0^{\mathrm{b}}$ & $0.0 \pm 0.0^{\mathrm{b}}$ & $0.0 \pm 0.0^{\mathrm{b}}$ & $0.1 \pm 0.2^{b}$ \\
\hline $18: 2(n-6)$ & $5.1 \pm 0.0^{\mathrm{a}}$ & $2.3 \pm 0.0^{\mathrm{c}}$ & $2.3 \pm 0.1^{\mathrm{c}}$ & $3.0 \pm 0.1^{b}$ & $1.3 \pm 0.0^{\mathrm{d}}$ \\
\hline $18: 3(n-6)$ & $0.3 \pm 0.0^{\mathrm{a}}$ & $0.8 \pm 0.0^{\mathrm{a}}$ & $0.8 \pm 0.0^{\mathrm{a}}$ & $0.5 \pm 0.0^{\mathrm{a}}$ & $0.7 \pm 0.4^{\mathrm{a}}$ \\
\hline $18: 3(n-3)$ & $0.0 \pm 0.0^{\mathrm{d}}$ & $2.9 \pm 0.0^{\mathrm{b}}$ & $2.1 \pm 0.0^{\mathrm{c}}$ & $4.2 \pm 0.2^{\mathrm{a}}$ & $0.0 \pm 0.0^{\mathrm{d}}$ \\
\hline $18: 4(n-3)$ & $1.3 \pm 0.0^{\mathrm{d}}$ & $7.9 \pm 0.1^{\mathrm{b}}$ & $5.4 \pm 0.3^{c}$ & $10.6 \pm 0.9^{\mathrm{a}}$ & $0.7 \pm 0.1^{\mathrm{d}}$ \\
\hline $20: 2(n-6)$ & $1.1 \pm 0.0^{\mathrm{a}}$ & $1.1 \pm 0.2^{\mathrm{a}}$ & $0.8 \pm 0.0^{\mathrm{ab}}$ & $1.0 \pm 0.0^{\mathrm{ab}}$ & $0.6 \pm 0.3^{b}$ \\
\hline $20: 4(n-6)$ AA & $0.7 \pm 0.0^{\mathrm{c}}$ & $1.7 \pm 0.0^{\mathrm{b}}$ & $2.3 \pm 0.0^{\mathrm{b}}$ & $0.7 \pm 0.0^{\mathrm{c}}$ & $4.6 \pm 0.1^{\mathrm{a}}$ \\
\hline 20:5(n-3) EPA & $5.7 \pm 0.0^{\mathrm{c}}$ & $19.0 \pm 0.1^{\mathrm{ab}}$ & $16.8 \pm 0.6^{\mathrm{ab}}$ & $13.6 \pm 0.3^{b}$ & $21.9 \pm 0.9^{\mathrm{a}}$ \\
\hline $22: 2$ NMI & $2.1 \pm 0.1^{\mathrm{a}}$ & $0.6 \pm 0.1^{\mathrm{d}}$ & $1.0 \pm 0.0^{\mathrm{c}}$ & $0.5 \pm 0.1^{\mathrm{d}}$ & $1.2 \pm 0.1^{\mathrm{b}}$ \\
\hline $22: 5(n-6)$ & $0.0 \pm 0.0^{\mathrm{d}}$ & $1.4 \pm 0.0^{\mathrm{b}}$ & $1.0 \pm 0.0^{\mathrm{c}}$ & $1.9 \pm 0.0^{\mathrm{a}}$ & $0.0 \pm 0.0^{\mathrm{d}}$ \\
\hline 22:6(n-3) DHA & $3.4 \pm 0.0^{\mathrm{d}}$ & $7.5 \pm 0.1^{b}$ & $5.9 \pm 0.1^{\mathrm{c}}$ & $9.5 \pm 0.1^{\mathrm{a}}$ & $1.5 \pm 0.2^{\mathrm{e}}$ \\
\hline$\Sigma$ SAFA & $39.2 \pm 0.1^{\mathrm{a}}$ & $29.0 \pm 0.4^{\mathrm{b}}$ & $32.7 \pm 0.9^{b}$ & $31.2 \pm 0.9^{b}$ & $31.8 \pm 1.1^{\mathrm{b}}$ \\
\hline$\Sigma$ DMA & $0.3 \pm 0.0^{\mathrm{a}}$ & $0.1 \pm 0.0^{\mathrm{b}}$ & $0.2 \pm 0.0^{\mathrm{ab}}$ & $0.2 \pm 0.0^{\mathrm{b}}$ & $0.2 \pm 0.0^{\mathrm{ab}}$ \\
\hline$\Sigma$ MUFA & $37.4 \pm 0.0^{\mathrm{a}}$ & $21.0 \pm 0.0^{\mathrm{d}}$ & $23.9 \pm 0.5^{\mathrm{c}}$ & $20.5 \pm 0.4^{\mathrm{d}}$ & $27.2 \pm 1.4^{\mathrm{b}}$ \\
\hline$\sum \mathrm{n}-9$ & $17.9 \pm 0.0^{\mathrm{a}}$ & $5.7 \pm 0.2^{b}$ & $5.5 \pm 0.1^{b}$ & $7.4 \pm 0.4^{\mathrm{b}}$ & $3.5 \pm 0.5^{\mathrm{b}}$ \\
\hline$\Sigma \mathrm{n}-7$ & $18.2 \pm 0.0^{\mathrm{b}}$ & $14.7 \pm 0.2^{\mathrm{bc}}$ & $17.6 \pm 0.5^{\mathrm{b}}$ & $12.6 \pm 0.0^{\mathrm{c}}$ & $22.7 \pm 1.5^{\mathrm{a}}$ \\
\hline$\Sigma$ PUFA & $21.1 \pm 0.0^{\mathrm{c}}$ & $49.4 \pm 0.5^{\mathrm{a}}$ & $42.3 \pm 1.4^{\mathrm{ab}}$ & $47.6 \pm 1.4^{\mathrm{a}}$ & $39.6 \pm 1.3^{b}$ \\
\hline$\sum n-4$ & $0.0 \pm 0.0^{\mathrm{a}}$ & $2.3 \pm 0.1^{\mathrm{a}}$ & $3.0 \pm 0.2^{\mathrm{a}}$ & $0.8 \pm 0.0^{\mathrm{a}}$ & $1.2 \pm 2.5^{\mathrm{a}}$ \\
\hline$\Sigma \mathrm{n}-6$ & $8.2 \pm 0.0^{\mathrm{a}}$ & $8.1 \pm 0.5^{\mathrm{a}}$ & $7.8 \pm 0.2^{\mathrm{a}}$ & $7.1 \pm 0.0^{\mathrm{a}}$ & $8.3 \pm 0.9^{a}$ \\
\hline$\Sigma n-3$ & $12.9 \pm 0.0^{\mathrm{a}}$ & $40.2 \pm 0.0^{\mathrm{b}}$ & $32.3 \pm 1.0^{\mathrm{c}}$ & $41.2 \pm 1.4^{\mathrm{b}}$ & $25.7 \pm 1.0^{\mathrm{d}}$ \\
\hline$\Sigma$ NMID & $2.3 \pm 0.1^{\mathrm{a}}$ & $0.6 \pm 0.1^{b}$ & $1.1 \pm 0.0^{\mathrm{bc}}$ & $0.7 \pm 0.2^{b}$ & $1.4 \pm 0.3^{\mathrm{c}}$ \\
\hline$n-3 / n-6$ & $1.6 \pm 0.0^{\mathrm{d}}$ & $5.0 \pm 0.3^{\mathrm{a}}$ & $4.1 \pm 0.0^{\mathrm{b}}$ & $5.5 \pm 0.2^{\mathrm{a}}$ & $3.1 \pm 0.4^{\mathrm{c}}$ \\
\hline $22: 6 / 20: 5$ & $0.6 \pm 0.0^{\mathrm{b}}$ & $0.4 \pm 0.0^{c}$ & $0.3 \pm 0.0^{\mathrm{d}}$ & $0.7 \pm 0.0^{\mathrm{a}}$ & $0.1 \pm 0.0^{\mathrm{e}}$ \\
\hline $22: 5 / 20: 4$ & $0.0 \pm 0.0^{\mathrm{d}}$ & $0.8 \pm 0.0^{\mathrm{b}}$ & $0.5 \pm 0.0^{\mathrm{c}}$ & $2.9 \pm 0.1^{\mathrm{a}}$ & $0.0 \pm 0.0^{\mathrm{d}}$ \\
\hline $20: 5 / 20: 4$ & $8.0 \pm 0.0^{c}$ & $10.8 \pm 0.1^{\mathrm{b}}$ & $7.3 \pm 0.2^{\mathrm{c}}$ & $20.4 \pm 1.3^{\mathrm{a}}$ & $4.8 \pm 0.1^{\mathrm{d}}$ \\
\hline
\end{tabular}

Values with same letters in the same row are not significant at $p>0.05$. 
Table 5

Fatty acid composition of total polar lipids of $R$. decussatus larvae (expressed as mean \pm S.D. of fatty acids of polar lipids) on day 2 and on day 22. C: $\operatorname{diet}$ C. muelleri; IP: I. galbana and P. lutheri (1:1); IPC: diet I. galbana, P. lutheri and C. muelleri (1:1:1); IP2C: diet I. galbana, P. lutheri and C. muelleri (1:1:2). Fatty acids representing less than $1 \%$ of total fatty acids were excluded from the list.

\begin{tabular}{|c|c|c|c|c|c|}
\hline & Day 2 & Day 22-IPC & Day 22-IP2C & Day 22-IP & Day 22-C \\
\hline $14: 0$ & $1.4 \pm 0.0^{\mathrm{c}}$ & $2.2 \pm 0.0^{\mathrm{a}}$ & $2.2 \pm 0.1^{\mathrm{a}}$ & $2.4 \pm 0.1^{\mathrm{a}}$ & $2.0 \pm 0.2^{b}$ \\
\hline $16: 0$ & $17.8 \pm 1.0^{\mathrm{c}}$ & $16.8 \pm 0.1^{\mathrm{b}}$ & $16.1 \pm 0.1^{\mathrm{b}}$ & $19.7 \pm 0.4^{\mathrm{a}}$ & $13.5 \pm 0.4^{\mathrm{d}}$ \\
\hline 18:0 & $6.0 \pm 0.5^{\mathrm{d}}$ & $6.7 \pm 0.3^{c}$ & $7.2 \pm 0.2^{b}$ & $6.6 \pm 0.1^{\mathrm{c}}$ & $9.0 \pm 0.1^{\mathrm{a}}$ \\
\hline 20:0 & $1.2 \pm 0.1^{\mathrm{a}}$ & $0.8 \pm 0.0^{c}$ & $0.7 \pm 0.0^{\mathrm{c}}$ & $1.0 \pm 0.0^{\mathrm{b}}$ & $0.0 \pm 0.0^{\mathrm{d}}$ \\
\hline $22: 0$ & $2.2 \pm 1.6^{\mathrm{a}}$ & $1.0 \pm 0.5^{\mathrm{b}}$ & $0.4 \pm 0.0^{\mathrm{b}}$ & $0.5 \pm 0.2^{b}$ & $0.2 \pm 0.1^{b}$ \\
\hline $16: 1(n-9)$ & $1.7 \pm 0.0^{\mathrm{a}}$ & $0.6 \pm 0.1^{\mathrm{d}}$ & $0.8 \pm 0.2^{c}$ & $0.3 \pm 0.0^{\mathrm{e}}$ & $1.3 \pm 0.1^{\mathrm{b}}$ \\
\hline $16: 1(n-7)$ & $3.2 \pm 0.0^{\mathrm{a}}$ & $1.5 \pm 0.0^{\mathrm{d}}$ & $1.7 \pm 0.0^{c}$ & $1.4 \pm 0.1^{\mathrm{e}}$ & $2.8 \pm 0.1^{b}$ \\
\hline $16: 1(n-13) t$ & $1.0 \pm 0.1^{\mathrm{a}}$ & $0.2 \pm 0.0^{\mathrm{d}}$ & $0.3 \pm 0.0^{c}$ & $0.2 \pm 0.0^{\mathrm{d}}$ & $0.4 \pm 0.0^{\mathrm{b}}$ \\
\hline $18: 1(n-9)$ & $2.4 \pm 0.1^{\mathrm{b}}$ & $2.4 \pm 0.1^{\mathrm{b}}$ & $2.4 \pm 0.1^{\mathrm{b}}$ & $2.7 \pm 0.1^{\mathrm{a}}$ & $2.6 \pm 0.3^{\mathrm{ab}}$ \\
\hline $18: 1(n-7)$ & $2.4 \pm 0.1^{\mathrm{d}}$ & $2.7 \pm 0.1^{\mathrm{c}}$ & $3.2 \pm 0.1^{\mathrm{b}}$ & $3.1 \pm 0.2^{\mathrm{b}}$ & $3.4 \pm 0.1^{\mathrm{a}}$ \\
\hline $20: 1(n-11)$ & $2.1 \pm 0.0^{\mathrm{a}}$ & $2.1 \pm 0.1^{\mathrm{a}}$ & $2.4 \pm 0.1^{\mathrm{b}}$ & $1.9 \pm 0.1^{\mathrm{c}}$ & $2.6 \pm 0.1^{\mathrm{d}}$ \\
\hline 20:1(n-9) & $1.4 \pm 0.0^{\mathrm{a}}$ & $1.2 \pm 0.1^{b}$ & $1.1 \pm 0.1^{\mathrm{c}}$ & $1.4 \pm 0.1^{\mathrm{a}}$ & $0.8 \pm 0.0^{\mathrm{d}}$ \\
\hline $20: 1(n-7)$ & $1.3 \pm 0.0^{\mathrm{b}}$ & $1.0 \pm 0.0^{\mathrm{d}}$ & $1.2 \pm 0.0^{c}$ & $0.9 \pm 0.0^{\mathrm{e}}$ & $1.5 \pm 0.0^{\mathrm{a}}$ \\
\hline $18: 2(n-6)$ & $0.5 \pm 0.0^{\mathrm{ab}}$ & $0.4 \pm 0.0^{b}$ & $0.5 \pm 0.0^{\mathrm{ab}}$ & $0.5 \pm 0.1^{\mathrm{ab}}$ & $0.5 \pm 0.1^{\mathrm{a}}$ \\
\hline $18: 3(n-3)$ & $1.0 \pm 0.8^{\mathrm{c}}$ & $1.7 \pm 0.5^{b}$ & $1.4 \pm 0.3^{\mathrm{bc}}$ & $2.9 \pm 0.1^{\mathrm{a}}$ & $0.8 \pm 0.3^{c}$ \\
\hline $18: 4(n-3)$ & $0.8 \pm 0.0^{\mathrm{d}}$ & $1.0 \pm 0.0^{b}$ & $0.9 \pm 0.0^{\mathrm{c}}$ & $1.4 \pm 0.1^{\mathrm{a}}$ & $0.0 \pm 0.0^{\mathrm{e}}$ \\
\hline $20: 2(n-6)$ & $2.3 \pm 0.6^{\mathrm{a}}$ & $2.3 \pm 0.2^{\mathrm{a}}$ & $1.8 \pm 0.0^{\mathrm{b}}$ & $2.1 \pm 0.1^{\mathrm{ab}}$ & $1.0 \pm 0.0^{c}$ \\
\hline $20: 3(n-6)$ & $0.1 \pm 0.0^{\mathrm{d}}$ & $0.2 \pm 0.0^{c}$ & $0.2 \pm 0.0^{\mathrm{b}}$ & $0.1 \pm 0.0^{\mathrm{d}}$ & $0.4 \pm 0.0^{\mathrm{a}}$ \\
\hline $20: 4(n-6)$ AA & $2.5 \pm 0.0^{\mathrm{d}}$ & $2.8 \pm 0.2^{\mathrm{c}}$ & $3.3 \pm 0.1^{\mathrm{b}}$ & $1.7 \pm 0.0^{\mathrm{e}}$ & $5.6 \pm 0.1^{\mathrm{a}}$ \\
\hline $20: 4(n-3)$ & $0.3 \pm 0.0^{\mathrm{b}}$ & $0.3 \pm 0.0^{\mathrm{b}}$ & $0.2 \pm 0.0^{\mathrm{c}}$ & $0.4 \pm 0.0^{\mathrm{a}}$ & $0.1 \pm 0.0^{\mathrm{d}}$ \\
\hline 20:5(n-3) EPA & $14.0 \pm 0.0^{b}$ & $10.3 \pm 0.4^{\mathrm{d}}$ & $11.2 \pm 0.3^{\mathrm{c}}$ & $8.5 \pm 0.3^{\mathrm{e}}$ & $17.1 \pm 0.5^{\mathrm{a}}$ \\
\hline $21: 4(n-6)$ & $0.5 \pm 0.0^{\mathrm{d}}$ & $0.6 \pm 0.1^{\mathrm{c}}$ & $0.7 \pm 0.0^{\mathrm{b}}$ & $0.0 \pm 0.0^{\mathrm{e}}$ & $2.6 \pm 0.1^{\mathrm{a}}$ \\
\hline $21: 5(n-3)$ & $1.7 \pm 0.2^{c}$ & $2.6 \pm 0.3^{b}$ & $2.5 \pm 0.0^{\mathrm{b}}$ & $2.3 \pm 0.1^{\mathrm{b}}$ & $3.2 \pm 0.1^{\mathrm{a}}$ \\
\hline 22:2 NMI & $5.5 \pm 0.0^{\mathrm{d}}$ & $8.1 \pm 0.3^{c}$ & $9.3 \pm 0.1^{\mathrm{b}}$ & $7.5 \pm 0.2^{\mathrm{d}}$ & $10.6 \pm 0.2^{\mathrm{a}}$ \\
\hline $22: 4(n-6)$ & $2.7 \pm 0.1^{\mathrm{a}}$ & $2.0 \pm 0.4^{\mathrm{b}}$ & $1.3 \pm 0.1^{\mathrm{c}}$ & $0.4 \pm 0.1^{\mathrm{d}}$ & $2.8 \pm 0.1^{\mathrm{a}}$ \\
\hline $22: 4(n-9) t$ & $0.0 \pm 0.0^{\mathrm{b}}$ & $1.1 \pm 1.0^{\mathrm{a}}$ & $0.7 \pm 0.1^{\mathrm{ab}}$ & $1.0 \pm 0.6^{\mathrm{a}}$ & $0.4 \pm 0.1^{b}$ \\
\hline $22: 5(n-6)$ & $2.2 \pm 0.0^{c}$ & $5.4 \pm 1.2^{\mathrm{ab}}$ & $4.7 \pm 0.1^{b}$ & $5.7 \pm 0.4^{\mathrm{a}}$ & $1.6 \pm 0.2^{\mathrm{c}}$ \\
\hline $22: 5(n-3)$ & $3.4 \pm 0.0^{\mathrm{b}}$ & $1.8 \pm 0.1^{\mathrm{d}}$ & $2.2 \pm 0.1^{\mathrm{c}}$ & $1.4 \pm 0.0^{\mathrm{e}}$ & $3.7 \pm 0.1^{\mathrm{a}}$ \\
\hline $22: 6(n-3) \mathrm{DH}$ & $16.7 \pm 0.1^{c}$ & $18.7 \pm 1.0^{\mathrm{b}}$ & $18.7 \pm 0.3^{b}$ & $21.3 \pm 0.6^{\mathrm{a}}$ & $8.7 \pm 0.3^{\mathrm{d}}$ \\
\hline 18:0dma & $8.4 \pm 0.1^{\mathrm{c}}$ & $10.2 \pm 2.1^{\mathrm{bc}}$ & $11.4 \pm 2.2^{\mathrm{b}}$ & $4.5 \pm 0.3^{\mathrm{d}}$ & $15.2 \pm 1.0^{\mathrm{a}}$ \\
\hline$\Sigma$ SAFA & $28.6 \pm 0.0^{\mathrm{b}}$ & $27.6 \pm 0.2^{\mathrm{c}}$ & $26.7 \pm 0.3^{\mathrm{d}}$ & $30.2 \pm 0.2^{\mathrm{a}}$ & $24.7 \pm 0.7^{\mathrm{e}}$ \\
\hline$\Sigma$ DMA & $8.4 \pm 0.1^{\mathrm{c}}$ & $10.4 \pm 2.2^{\mathrm{b}}$ & $11.7 \pm 2.2^{\mathrm{b}}$ & $4.7 \pm 0.3^{\mathrm{d}}$ & $15.4 \pm 1.0^{\mathrm{a}}$ \\
\hline$\Sigma$ MUFA & $15.5 \pm 0.2^{\mathrm{a}}$ & $11.9 \pm 0.5^{\mathrm{c}}$ & $13.2 \pm 0.1^{\mathrm{b}}$ & $12.1 \pm 0.3^{\mathrm{c}}$ & $15.3 \pm 0.4^{\mathrm{a}}$ \\
\hline$\sum n-9$ & $5.5 \pm 0.1^{\mathrm{a}}$ & $4.2 \pm 0.2^{c}$ & $4.3 \pm 0.0^{c}$ & $4.5 \pm 0.1^{\mathrm{bc}}$ & $4.7 \pm 0.3^{b}$ \\
\hline$\sum \mathrm{n}-7$ & $6.9 \pm 0.1^{\mathrm{b}}$ & $5.3 \pm 0.2^{\mathrm{d}}$ & $6.1 \pm 0.0^{\mathrm{c}}$ & $5.3 \pm 0.3^{\mathrm{d}}$ & $7.6 \pm 0.1^{\mathrm{a}}$ \\
\hline$\Sigma$ PUFA & $50.1 \pm 0.3^{b}$ & $52.2 \pm 1.1^{\mathrm{a}}$ & $50.6 \pm 0.5^{\mathrm{b}}$ & $50.2 \pm 0.2^{\mathrm{b}}$ & $49.3 \pm 0.5^{\mathrm{c}}$ \\
\hline$\sum n-4$ & $0.0 \pm 0.0^{\mathrm{c}}$ & $0.2 \pm 0.0^{\mathrm{a}}$ & $0.2 \pm 0.0 \mathrm{ab}$ & $0.2 \pm 0.0^{\mathrm{ab}}$ & $0.1 \pm 0.1^{\mathrm{b}}$ \\
\hline$\sum n-6$ & $12.2 \pm 0.8^{b}$ & $14.4 \pm 1.4^{\mathrm{a}}$ & $12.8 \pm 0.2^{\mathrm{b}}$ & $10.8 \pm 0.6^{\mathrm{c}}$ & $15.0 \pm 0.3^{\mathrm{a}}$ \\
\hline$\sum n-3$ & $40.2 \pm 0.5^{\mathrm{c}}$ & $43.0 \pm 1.0^{\mathrm{b}}$ & $42.4 \pm 0.4^{\mathrm{b}}$ & $45.0 \pm 0.4^{\mathrm{a}}$ & $35.7 \pm 0.5^{\mathrm{d}}$ \\
\hline$\Sigma$ NMID & $5.7 \pm 0.1^{\mathrm{e}}$ & $8.3 \pm 0.6^{c}$ & $9.4 \pm 0.1^{\mathrm{b}}$ & $7.4 \pm 0.4^{\mathrm{d}}$ & $10.7 \pm 0.2^{\mathrm{a}}$ \\
\hline$n-3 / n-6$ & $3.3 \pm 0.3^{\mathrm{b}}$ & $3.0 \pm 0.2^{c}$ & $3.3 \pm 0.1^{\mathrm{b}}$ & $4.2 \pm 0.2^{\mathrm{a}}$ & $2.4 \pm 0.1^{\mathrm{d}}$ \\
\hline $22: 6 / 20: 5$ & $1.2 \pm 0.0^{\mathrm{d}}$ & $1.8 \pm 0.1^{\mathrm{b}}$ & $1.7 \pm 0.0^{\mathrm{c}}$ & $2.5 \pm 0.0^{\mathrm{a}}$ & $0.5 \pm 0.0^{\mathrm{e}}$ \\
\hline $22: 5 / 20: 4$ & $0.9 \pm 0.0^{\mathrm{d}}$ & $2.0 \pm 0.6^{\mathrm{b}}$ & $1.4 \pm 0.0^{\mathrm{c}}$ & $3.4 \pm 0.3^{\mathrm{a}}$ & $0.3 \pm 0.0^{\mathrm{e}}$ \\
\hline $20: 5 / 20: 4$ & $5.7 \pm 0.1^{\mathrm{a}}$ & $3.7 \pm 0.3^{\mathrm{c}}$ & $3.3 \pm 0.2^{\mathrm{d}}$ & $5.0 \pm 0.2^{b}$ & $3.0 \pm 0.0^{\mathrm{e}}$ \\
\hline
\end{tabular}

Values with same letters in the same row are not significant at $p>0.05$. 


\section{Table 6}

Variations of fatty acids in neutral and polar lipids of 22 day-old larvae with respect to 2 day-old larvae (D-larvae) expressed in percentage of fatty acid gains or losses. Variations were calculated from mean values. Fatty acids representing less than $1 \%$ of variation related to total fatty acids were excluded from the list. C: $\operatorname{diet} C$. muelleri; IP: I. galbana and P. lutheri (1:1); IPC: diet I. galbana, P. lutheri and C. muelleri (1:1:1); IP2C: diet I. galbana, P. lutheri and C. muelleri (1:1:2).

\begin{tabular}{|c|c|c|c|c|c|c|c|c|}
\hline & Neutral & ipids & & & Polar lip & ids & & \\
\hline & IPC & IP2C & IP & $\mathrm{C}$ & IPC & IP2C & IP & $\mathrm{C}$ \\
\hline $14: 0$ & 14.2 & 16.5 & 12.9 & 19.2 & 2.4 & 2.4 & 2.4 & 1.9 \\
\hline $16: 0$ & 10.0 & 9.7 & 13.7 & 9.2 & 17.3 & 16.4 & 19.0 & 12.6 \\
\hline 18:0 & 2.7 & 3.3 & 3.1 & 2.2 & 7.3 & 7.7 & 6.3 & 9.3 \\
\hline $16: 1(n-7)$ & 8.7 & 9.7 & 6.9 & 14.4 & 1.4 & 1.6 & 1.0 & 2.9 \\
\hline $18: 1(n-9)$ & 3.7 & 2.0 & 5.2 & 1.2 & 2.5 & 2.5 & 2.6 & 2.8 \\
\hline $18: 1(n-7)$ & 5.6 & 6.8 & 4.8 & 8.7 & 2.9 & 3.3 & 2.9 & 3.6 \\
\hline $20: 1(n-11)$ & 0.1 & 0.0 & 0.1 & 0.1 & 2.1 & 2.5 & 1.9 & 2.6 \\
\hline $20: 1(n-9)$ & 0.5 & 0.5 & 0.6 & $\quad 0.2$ & 1.3 & 1.1 & 1.4 & 0.7 \\
\hline $20: 1(n-7)$ & 0.4 & 0.5 & 0.3 & 0.6 & 1.0 & 1.2 & 0.8 & 1.5 \\
\hline $16: 2(n-4)$ & 0.9 & 1.1 & 0.6 & 1.7 & 0.0 & 0.0 & 0.0 & 0.0 \\
\hline $16: 3(n-4)$ & 1.2 & 1.9 & 0.0 & 3.9 & 0.0 & 0.0 & 0.0 & 0.0 \\
\hline $18: 2(n-6)$ & 2.2 & 1.7 & 2.9 & 0.9 & 0.4 & 0.5 & 0.5 & 0.6 \\
\hline $18: 3(n-6)$ & 0.8 & 1.0 & 0.6 & 0.5 & 0.2 & 0.1 & 0.1 & 0.0 \\
\hline $18: 3(n-3)$ & 3.2 & 2.6 & 4.7 & 0.0 & 2.4 & 2.2 & 2.6 & 0.8 \\
\hline $18: 4(n-3)$ & 8.2 & 6.5 & 11.9 & 0.7 & 1.1 & 0.9 & 1.5 & -0.1 \\
\hline $20: 2(n-6)$ & 1.1 & 1.2 & 1.0 & 0.5 & 2.3 & 1.9 & 2.1 & 0.9 \\
\hline 20:4(n-6) AA & 2.0 & 2.6 & 0.7 & 5.1 & 2.7 & 3.3 & 1.6 & 6.0 \\
\hline 20:5(n-3) EPA & 20.2 & 19.6 & 14.5 & 23.9 & 9.3 & 10.3 & 7.7 & 17.0 \\
\hline $21: 4(n-6)$ & 0.1 & 0.0 & 0.0 & 0.5 & 0.5 & 0.8 & -0.1 & 2.9 \\
\hline $21: 5(n-3)$ & 0.5 & 0.5 & 0.5 & 0.7 & 2.5 & 2.5 & 2.4 & 3.4 \\
\hline $22: 2 \mathrm{NMI}$ & 0.5 & 0.7 & 0.4 & 1.1 & 8.2 & 9.4 & 7.9 & 11.2 \\
\hline $22: 4(n-6)$ & 0.2 & 0.4 & 0.1 & 0.1 & 1.6 & 1.2 & 0.1 & 3.0 \\
\hline $22: 4(n-9) t$ & 0.0 & 0.0 & 0.0 & 0.0 & 1.4 & 0.7 & 1.9 & 0.5 \\
\hline $22: 5(n-6)$ & 1.6 & 1.3 & 2.1 & 0.0 & 5.8 & 4.7 & 7.1 & 1.7 \\
\hline $22: 5(n-3)$ & 0.4 & 0.1 & 0.3 & 0.4 & 1.6 & 1.9 & 1.1 & 3.8 \\
\hline 22:6(n-3) DHA & 8.3 & 6.6 & 10.1 & 1.3 & 18.2 & 17.9 & 22.5 & 7.9 \\
\hline 18:0dma & 0.1 & 0.2 & 0.2 & 0.2 & 7.5 & 8.9 & 6.6 & 15.9 \\
\hline$\Sigma$ SFAs & 27.2 & 30.0 & 29.8 & 30.7 & 28.5 & 27.6 & 29.1 & 23.7 \\
\hline$\Sigma$ DMAs & 0.1 & 0.2 & 0.2 & 0.2 & 7.7 & 9.1 & 6.9 & 16.2 \\
\hline$\Sigma$ MUFAs & 19.8 & 20.5 & 18.7 & 26.5 & 11.8 & 13.1 & 11.0 & 15.7 \\
\hline$\sum n-9$ & 4.6 & 2.8 & 6.4 & 1.9 & 4.2 & 4.2 & 4.1 & 4.8 \\
\hline$\Sigma \mathrm{n}-7$ & 14.7 & 16.9 & 12.0 & 23.7 & 5.3 & 6.1 & 4.7 & 7.9 \\
\hline$\Sigma$ PUFAs & 52.4 & 48.7 & 51.0 & 41.5 & 51.3 & 49.8 & 51.8 & 49.3 \\
\hline$\sum n-4$ & 2.5 & 3.4 & 0.9 & 1.0 & 0.3 & 0.2 & 0.2 & 0.2 \\
\hline$\Sigma n-6$ & 8.4 & 8.6 & 7.5 & 8.1 & 14.3 & 12.9 & 11.4 & 15.6 \\
\hline$\Sigma n-3$ & 42.9 & 37.8 & 44.6 & 27.3 & 42.5 & 41.3 & 47.2 & 35.2 \\
\hline$\Sigma$ NMIDs & 0.6 & 0.9 & 0.5 & 1.2 & 8.3 & 9.5 & 8.1 & 11.3 \\
\hline
\end{tabular}




\section{Table 7}

Matrix of Pearson correlation coefficients between shell size or survival of 22-day-old larvae with dietary and larval proximate biochemical and fatty acid composition. Values for proximate biochemical composition of the algae were based in $\mu \mathrm{g} \mathrm{mg} \mathrm{sample}{ }^{-1}$ and for the larvae were based in $\mathrm{ng}$ individual ${ }^{-1}$.

Values for fatty acid composition of the algae were based in percentage of total FA and for the larvae were based ng individual ${ }^{-1}$.

\begin{tabular}{|c|c|c|c|}
\hline \multicolumn{2}{|c|}{ Independent variables } & \multicolumn{2}{|c|}{ Dependent variables } \\
\hline & & Shell size $^{\mathrm{a}}(\mathrm{n}=8)$ & $\operatorname{Survival}^{\mathrm{b}}(\mathrm{n}=8)$ \\
\hline \multirow[t]{12}{*}{ Diet } & Protein & $-0.572 \square$ & -0.009 \\
\hline & Lipids & -0.746 & -0.528 \\
\hline & Carbohydrates & -0.954 & -0.863 \\
\hline & $16: 0$ & -0.953 & -0.634 \\
\hline & 18:0 & 0.022 & 0.003 \\
\hline & $\mathrm{AA}$ & 0.879 & 0.567 \\
\hline & EPA & 0.540 & -0.078 \\
\hline & DHA & -0.830 & -0.654 \\
\hline & DPA & -0.849 & -0.654 \\
\hline & SFAs & 0.430 & 0.406 \\
\hline & MUFAs & 0.639 & 0.544 \\
\hline & PUFAs & -0.503 & -0.457 \\
\hline \multirow{3}{*}{ Larvae } & Protein & 0.381 & 0.544 \\
\hline & Lipids & -0.673 & -0.073 \\
\hline & Carbohydrates & -0.106 & 0.147 \\
\hline \multirow[t]{11}{*}{ Larvae NL } & $16: 0$ & -0.515 & -0.585 \\
\hline & $18: 0$ & -0.070 & -0.399 \\
\hline & AA & 0.949 & 0.570 \\
\hline & EPA & 0.373 & 0.172 \\
\hline & DHA & -0.498 & -0.312 \\
\hline & & -0.586 & -0.318 \\
\hline & 18:0dma & -0.099 & -0.441 \\
\hline & 22:2NMID & 0.332 & 0.327 \\
\hline & SFAs & -0.237 & -0.339 \\
\hline & MUFAs & -0.055 & -0.077 \\
\hline & PUFAs & -0.108 & -0.133 \\
\hline \multirow[t]{11}{*}{ Larvae PL } & $16: 0$ & 0.210 & 0.380 \\
\hline & 18:0 & 0.912 & 0.710 \\
\hline & AA & 0.930 & 0.589 \\
\hline & EPA & 0.951 & 0.570 \\
\hline & DHA & -0.256 & 0.140 \\
\hline & DPA & -0.213 & -0.149 \\
\hline & 18:0dma & 0.619 & 0.480 \\
\hline & 22:2NMID & 0.911 & 0.775 \\
\hline & SFAs & 0.442 & 0.515 \\
\hline & MUFAs & 0.939 & 0.741 \\
\hline & PUFAs & 0.523 & 0.467 \\
\hline
\end{tabular}

Significant probabilities are in bold $(p<0.05)$.

${ }^{a}$ Measurement of mean shell height and length of 100 larvae.

${ }^{\mathrm{b}}$ Percent survival based on initial number of 2-day-old larvae. 


\section{Highlights}

1. We study the impact of four microalgal diets on biochemical and fatty composition of Ruditapes decussatus larvae.

2. R. decussatus larval diets may include the diatom Chaetoceros muelleri.

3. Increasing lipid and carbohydrate contents of the diets may reduce larval growth and survival respectively.

4. DHA deficiencies in the diet may not have deleterious effects on $R$. decussatus larval development.

5. Dietary AA is important for larval development. 